Prepared in cooperation with Blaine County, City of Hailey, City of Ketchum, The Nature Conservancy, City of Sun Valley, Sun Valley Water and Sewer District, Blaine Soil Conservation District, City of Bellevue, and Citizens for Smart Growth

\title{
Water-Resource Trends and Comparisons Between Partial Development and October 2006 Hydrologic Conditions, Wood River Valley, South-Central Idaho
}

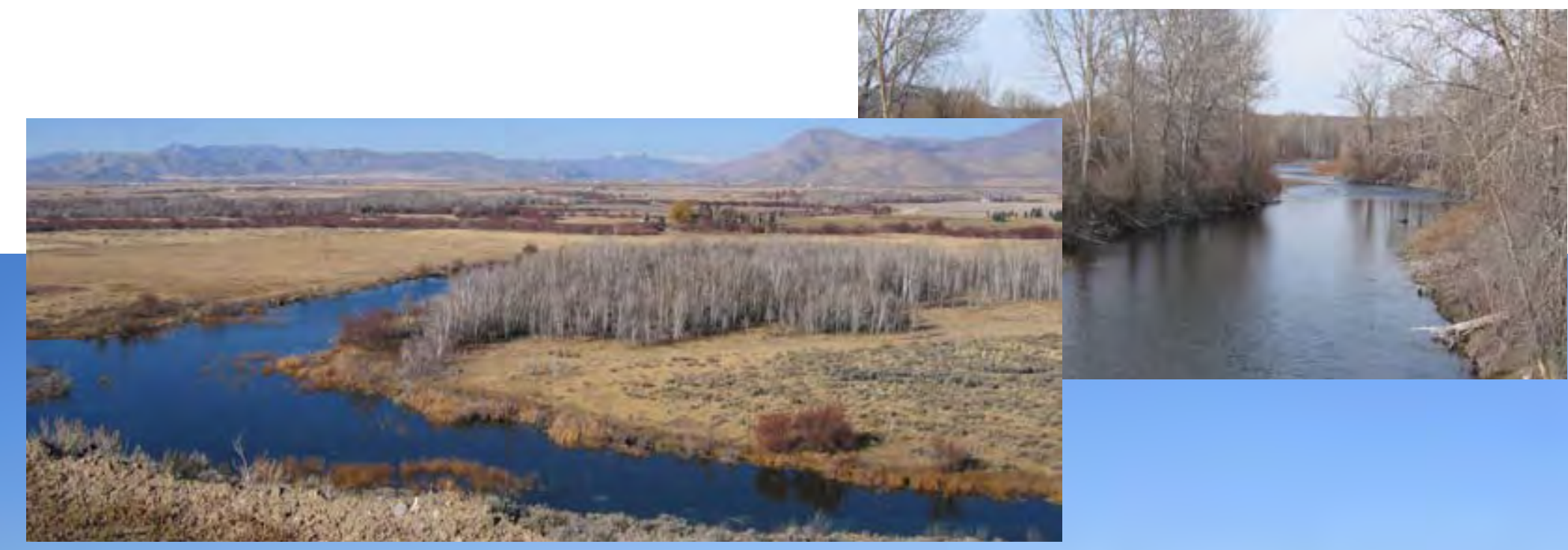

Scientific Investigations Report $2007-5258$ 


\section{Cover:}

Top: Silver Creek and the Bellevue fan looking northwest up the Wood River Valley from the Picabo Hills, Wood River Valley, south-central Idaho.

(Photograph taken by James R. Bartolino, U.S. Geological Survey, November 19, 2004.)

Middle: The Big Wood River looking south (downstream) of the U.S. 20 bridge at Stanton Crossing, Wood River Valley, south-central Idaho.

(Photograph taken by James R. Bartolino, U.S. Geological Survey, April 15, 2005.)

Bottom: The Big Wood River looking south (downstream) of the Glendale bridge,

Wood River Valley, south-central Idaho.

(Photograph taken by James R. Bartolino, U.S. Geological Survey, June 21, 2006.) 


\section{Water-Resource Trends and Comparisons Between Partial-Development and October 2006 Hydrologic Conditions, Wood River Valley, South-Central Idaho}

By Kenneth D. Skinner, James R. Bartolino, and Andrew W. Tranmer

Prepared in cooperation with Blaine County, City of Hailey, City of Ketchum, The Nature Conservancy, City of Sun Valley, Sun Valley Water and Sewer District, Blaine Soil Conservation District, City of Bellevue, and Citizens for Smart Growth

Scientific Investigations Report 2007-5258 


\section{U.S. Department of the Interior DIRK KEMPTHORNE, Secretary}

\section{U.S. Geological Survey \\ Mark D. Myers, Director}

\section{U.S. Geological Survey, Reston, Virginia: 2007}

For product and ordering information:

World Wide Web: http://www.usgs.gov/pubprod

Telephone: 1-888-ASK-USGS

For more information on the USGS--the Federal source for science about the Earth, its natural and living resources, natural hazards, and the environment:

World Wide Web: http://www.usgs.gov

Telephone: 1-888-ASK-USGS

Any use of trade, product, or firm names is for descriptive purposes only and does not imply endorsement by the U.S. Government.

Although this report is in the public domain, permission must be secured from the individual copyright owners to reproduce any copyrighted materials contained within this report.

Suggested citation:

Skinner, K.D., Bartolino, J.R., and Tranmer, A.W., 2007, Water-resource trends and comparisons between partial development and October 2006 hydrologic conditions, Wood River Valley, south-central, Idaho: U.S. Geological Survey Scientific Investigations Report 2007-5258, 30 p. 


\section{Contents}

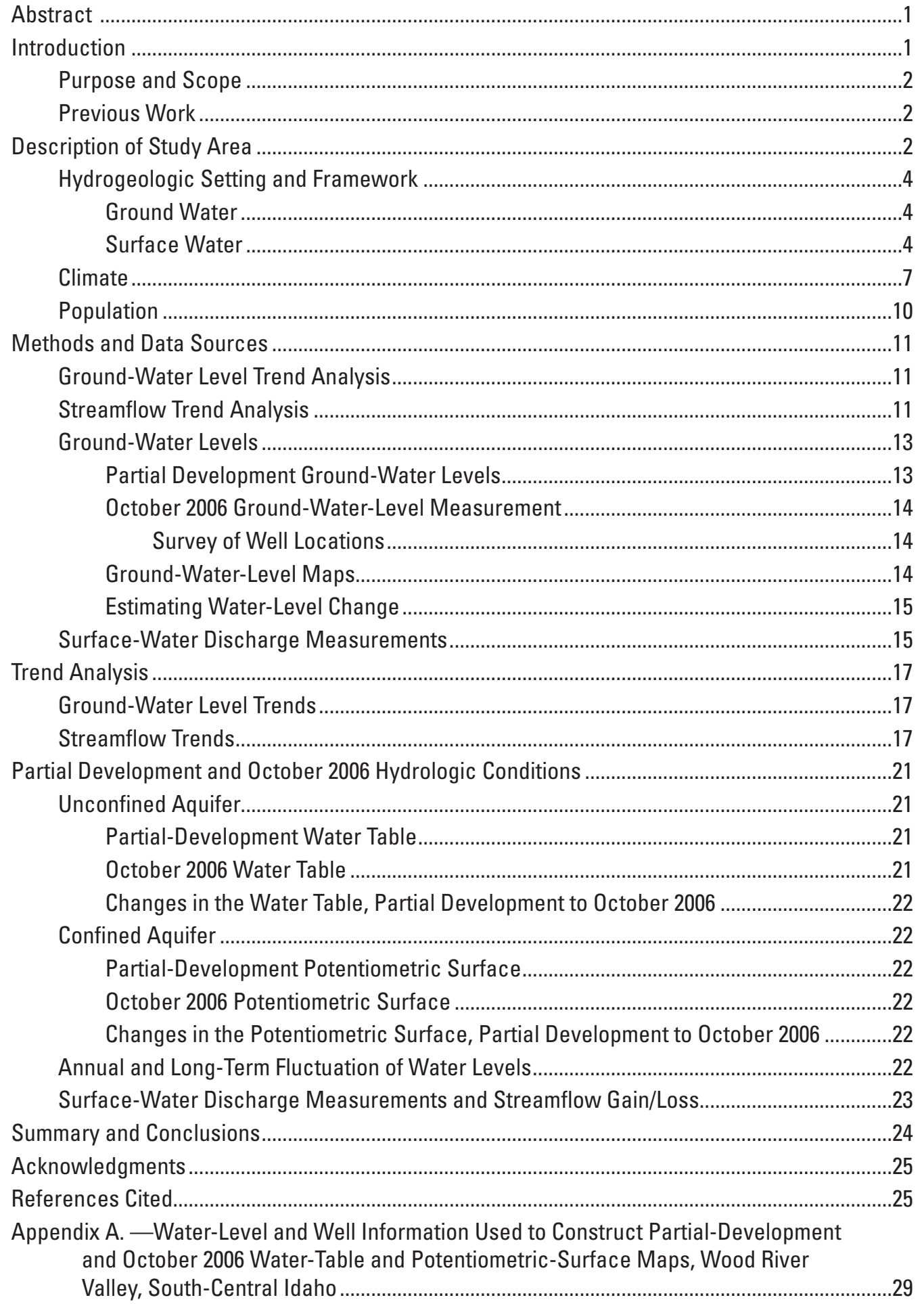




\section{Plates}

Plate 1. Partial-development water-table map of the unconfined aquifer, Wood River Valley, south-central Idaho, 1952-86.

Plate 2. October 2006 water-table map of the unconfined aquifer, Wood River Valley, south-central Idaho, October 23-27, 2006.

Plate 3. Changes in the water-table altitude of the unconfined aquifer from partial development (1952-86) to October 2006, Wood River Valley, south-central Idaho.

Plate 4. Partial-development and October 2006 potentiometric surface and change maps of the confined aquifer, Wood River Valley, south-central Idaho.

\section{Figures}

Figure 1. Map showing location of communities, continuous streamflow-gaging stations, weather stations, and snow-survey sites, Wood River Valley, south-central Idaho

Figure 2. Graph showing Palmer drought severity index for Idaho climate zone 4

Figure 3. Graph showing Blaine County population by decennial census, 1900-2000, and projected 2005 population, south-central Idaho

Figure 4. Map showing location of surface-water discharge measurements, Wood River Valley, central Idaho, October 23-26, 2006

Figure 5. Graphs showing normalized residual plots of mean annual depth to water for three wells and total annual precipitation at the Ketchum Ranger Station, Wood River Valley, south-central Idaho

Figure 6. Graphs showing trend analysis of annual 7- and 30-day low streamflows for two gaging stations on the Big Wood River, south-central Idaho 19

Figure 7. Graph showing mean monthly discharge at Big Wood River near Bellevue, south-central Idaho, water years 1915-96.

\section{Tables}

Table 1. Continuous record streamflow-gaging stations within a 25-mile buffer of Wood River Valley, south-central Idaho

Table 2. Mean annual and annual peak flow from selected streamflow-gaging stations in and adjacent to Wood River Valley, south-central Idaho

Table 3. National Weather Service stations, AgriMet stations, and snow-survey sites in or near the Wood River Valley, south-central Idaho

Table 4. Summary of data from selected weather stations in and near the Wood River Valley, south-central Idaho

Table 5. Surface-water trend analyses for three streamflow-gaging stations, Wood River Valley, south-central Idaho

Table 6. Extremes of ground-water levels and annual variation for selected wells in the Wood River Valley, south-central Idaho, 1954-2006

Table 7. Streamflow measurements, Wood River Valley, south-central Idaho, October 23-26, 2006. 


\section{Conversion Factors, Datums, and Acronyms}

Conversion Factors

\begin{tabular}{lcl}
\hline Multiply & By & To obtain \\
\hline cubic foot per second $\left(\mathrm{ft}^{3} / \mathrm{s}\right)$ & 0.02832 & cubic meter per second $\left(\mathrm{m}^{3} / \mathrm{s}\right)$ \\
foot $(\mathrm{ft})$ & 0.3048 & meter $(\mathrm{m})$ \\
foot per mile $(\mathrm{ft} / \mathrm{mi})$ & 0.1894 & meter per kilometer $(\mathrm{m} / \mathrm{km})$ \\
inch (in.) & 2.54 & centimeter $(\mathrm{cm})$ \\
inch (in.) & 25.4 & millimeter $(\mathrm{mm})$ \\
mile (mi) & 1.609 & kilometer $(\mathrm{km})$ \\
square mile $\left(\mathrm{mi}^{2}\right)$ & 2.590 & square kilometer $\left(\mathrm{km}^{2}\right)$ \\
\hline
\end{tabular}

Temperature in degrees Fahrenheit $\left({ }^{\circ} \mathrm{F}\right)$ may be converted to degrees Celsius $\left({ }^{\circ} \mathrm{C}\right)$ as follows:

$$
{ }^{\circ} \mathrm{C}=\left({ }^{\circ} \mathrm{F}-32\right) / 1.8
$$

Datums

Vertical coordinate information is referenced to the "North American Vertical Datum of 1988 (NAVD 88)."

Horizontal coordinate information is referenced to the "North American Datum of 1983 (NAD 83)."

Elevation, as used in this report, refers to distance above the vertical datum.

Acronyms

\begin{tabular}{ll}
\hline Acronym & Definition \\
\hline BFI & Base Flow Index \\
DEM & digital elevation model \\
GIS & geographic information system \\
GPS & Global Positioning System \\
IDWR & Idaho Department of Water Resources \\
NWIS & National Water Information System \\
NWS & National Weather Service \\
PDSI & Palmer Drought Severity Index \\
RTK & real-time kinematic \\
USGS & U.S. Geological Survey \\
USEPA & U.S. Environmental Protection Agency \\
\hline
\end{tabular}


This page intentionally left blank. 


\title{
Water-Resource Trends and Comparisons Between Partial-Development and October 2006 Hydrologic Conditions, Wood River Valley, South-Central Idaho
}

\author{
By Kenneth D. Skinner, James R. Bartolino, and Andrew W. Tranmer
}

\section{Abstract}

This report analyzes trends in ground-water and surfacewater data, documents 2006 hydrologic conditions, and compares 2006 and historic ground-water data of the Wood River Valley of south-central Idaho. The Wood River Valley extends from Galena Summit southward to the Timmerman Hills. It is comprised of a single unconfined aquifer and an underlying confined aquifer present south of Baseline Road in the southern part of the study area. Streams are well-connected to the shallow unconfined aquifer. Because the entire population of the area depends on ground water for domestic supply, either from domestic or municipal-supply wells, rapid population growth since the 1970s has raised concerns about the continued availability of ground and surface water to support existing uses and streamflow. To help address these concerns, this report evaluates ground- and surface-water conditions in the area before and during the population growth that started in the 1970s.

Mean annual water levels in three wells (two completed in the unconfined aquifer and one in the confined aquifer) with more than 50 years of semi-annual measurements showed statistically significant declining trends.

Mean annual and monthly streamflow trends were analyzed for three gaging stations in the Wood River Valley. The Big Wood River at Hailey gaging station (13139500) showed a statistically significant trend of a 25-percent increase in mean monthly base flow for March over the 90 -year period of record, possibly because of earlier snowpack runoff. Both the 7-day and 30-day low-flow analyses for the Big Wood River near Bellevue gaging station (13141000) show a mean decrease of approximately 15 cubic feet per second since the 1940s, and mean monthly discharge showed statistically significant decreasing trends for December, January, and February. The Silver Creek at Sportsman Access near Picabo gaging station (13150430) also showed statistically significant decreasing trends in annual and mean monthly discharge for July through February and April from 1975 to 2005.

Comparisons of partial-development (ground-water conditions from 1952 to 1986) and 2006 ground-water resources in the Wood River Valley using a geographic information system indicate that most ground-water levels for the unconfined aquifer in the study area are either stable or declining. Declines are predominant in the southern part of the study area south of Hailey, and some areas exceed what is expected of natural fluctuations in ground-water levels. Some ground-water levels rose in the northern part of the study area; however, these increases are approximated due to a lack of water-level data in the area.

Ground-water level declines in the confined aquifer exceed the range of expected natural fluctuations in large areas of the confined aquifer in the southern part of the study area in the Bellevue fan. However, the results in this area are approximated due to limited available water-level data.

\section{Introduction}

Blaine County in south-central Idaho experienced a 40-percent population growth from 13,000 to more than 20,000 people from 1990 to 2000. Between April 1, 2000, and July 1, 2005, the county population increased by about 11.5 percent (U.S. Census Bureau, 2007). In addition to permanent residents, thousands of people annually visit Blaine County for winter and summer recreation. The entire population of the area depends on ground water for domestic supply, either from domestic or municipal-supply wells and surface water is used for recreation and irrigation supplies.

Water managers and private landowners are increasingly concerned about the effects of population growth on groundwater and surface-water supplies in the basins, including sustainability of ground-water resources and the effects of wastewater disposal on ground-water and surface-water quality. Development in recent years has been moving to tributary canyons of the upper Big Wood River basin, and residents in some canyon areas have reported declining ground-water levels. It is unclear at this time whether these declining ground-water levels are due to increased development or are a response to several years of drought conditions. In June 2005, Blaine County Commissioners approved an interim moratorium on selected development activities while the impacts of growth, including waterresource concerns, were evaluated. 
Although several technical reports have addressed specific areas and technical issues of the Wood River Valley, a current, holistic evaluation of water resources in these basins is needed to address concerns about current growth and development impacts and potential impacts of continued growth and development. In 2005, the U.S. Geological Survey (USGS) completed a project to compile and review existing information and data on the upper Big Wood River and Silver Creek basins, to identify gaps in information about water resources, and to prepare a workplan with priorities for data collection and interpretation to fill these gaps. This study is a part of that workplan, and it focuses on the effects of population growth on water resources in the Wood River Valley.

\section{Purpose and Scope}

The objectives of this study are (1) to provide data and interpretations about the water resources of the Wood River Valley to enable county and local governments to make informed decisions about those resources, and (2) to recommend additional data collection or studies necessary to furnish these data and interpretations to decision makers. This report analyzes trends in ground-water and surface-water data, documents 2006 hydrologic conditions, and compares 2006 and historic ground-water data of the Wood River Valley of south-central Idaho. Maps of partial-development and October 2006 ground-water levels are included for the confined and unconfined unconsolidated aquifers, as well as of estimated changes in those water levels between the two periods.

\section{Previous Work}

Smith (1959) published the earliest ground-water level map of the Wood River Valley, including Hailey and the southern part of the aquifer system. Subsequent maps of this area were developed by Castelin and Chapman (1972), Moreland (1977), and Brockway and Grover (1978). Luttrell and Brockway (1984) mapped ground-water levels in the valley south of Oregon Gulch; Frenzel's (1989) map included the valley north of Glendale Road. Small-scale ground-water level maps of all or part of the study area were compiled for regional studies by Mundorff and others (1964), Maupin (1992) Berenbrock and others (1995), and Briar and others (1996).

Surface waters of the Big Wood Valley have been examined and analyzed by Jones (1952), Smith (1960), Castelin and Chapman (1972), Moreland (1977), Brockway and Grover (1978), Luttrell and Brockway (1984), Frenzel (1989), Brockway and Kahlown (1994), and Wetzstein and others (1999). Brown (2000) summarized the information regarding ground water and surface water in Brockway and Kahlown (1994) and Wetzstein and others (1999). Many of these studies have recognized and emphasized the intimate association of the ground-water and surface-water systems.

\section{Description of Study Area}

The Wood River Valley of south-central Idaho extends from Galena Summit southward to the Timmerman Hills (fig. 1). The valley can be separated into upper and lower parts along an east-west line immediately south of Bellevue: the upper valley is narrow, broadening downstream to a maximum width of $2 \mathrm{mi}$ and the lower valley opens into a triangular fan (the Bellevue fan) about $9 \mathrm{mi}$ across at the southern end. The study area of this report is the combined contributing area (about $912 \mathrm{mi}^{2}$ ) for the streamflow-gaging stations and the aquifer system within the Wood River Valley extending from the boundary with the Sawtooth National Forest southward to the Timmerman Hills. The part of the aquifer system evaluated was constrained by available data and comprises an area of as much as $86 \mathrm{mi}^{2}$.

The Wood River Valley has a relatively flat bottom and land-surface elevations range from about 6,000 ft at the northern boundary of the study area to about $4,800 \mathrm{ft}$ at the southern boundary. A number of tributary canyons intersect the valley, the largest of which are Warm Springs Creek, Trail Creek, East Fork Big Wood River, and Croy Creek. The main valley and the tributary canyons have steep sides and are surrounded by highlands with peaks ranging to more than $11,000 \mathrm{ft}$ in elevation.

In addition to their different physiographic characteristics, the upper and lower valleys also differ in land use. The upper Wood River Valley is more developed and contains the communities of Sun Valley, Ketchum, Hailey, and Bellevue. Land use in the upper valley is predominantly housing, with many large homes situated on landscaped acreage. The lower Wood River Valley is primarily irrigated farms and ranches (irrigated by ground water and diverted surface water), and contains the small communities of Gannett and Picabo. Although some of the tributary canyons in the upper valley, such as Trail Creek and Warm Springs Creek have supported development for more than 50 years, more recent development has expanded into the valley's other tributary canyons. Three wastewater-treatment plants in the study area discharge to the Big Wood River; however, many homes rely on septic systems for waste disposal.

Most of the Wood River Valley is drained by the Big Wood River or its tributaries, except for the southeastern part of the Bellevue fan, which is drained by Silver Creek, a tributary to the Little Wood River. Several of the tributary canyons to the Big Wood River have perennial streams, although most of the streams flow only in response to precipitation or snowmelt. 


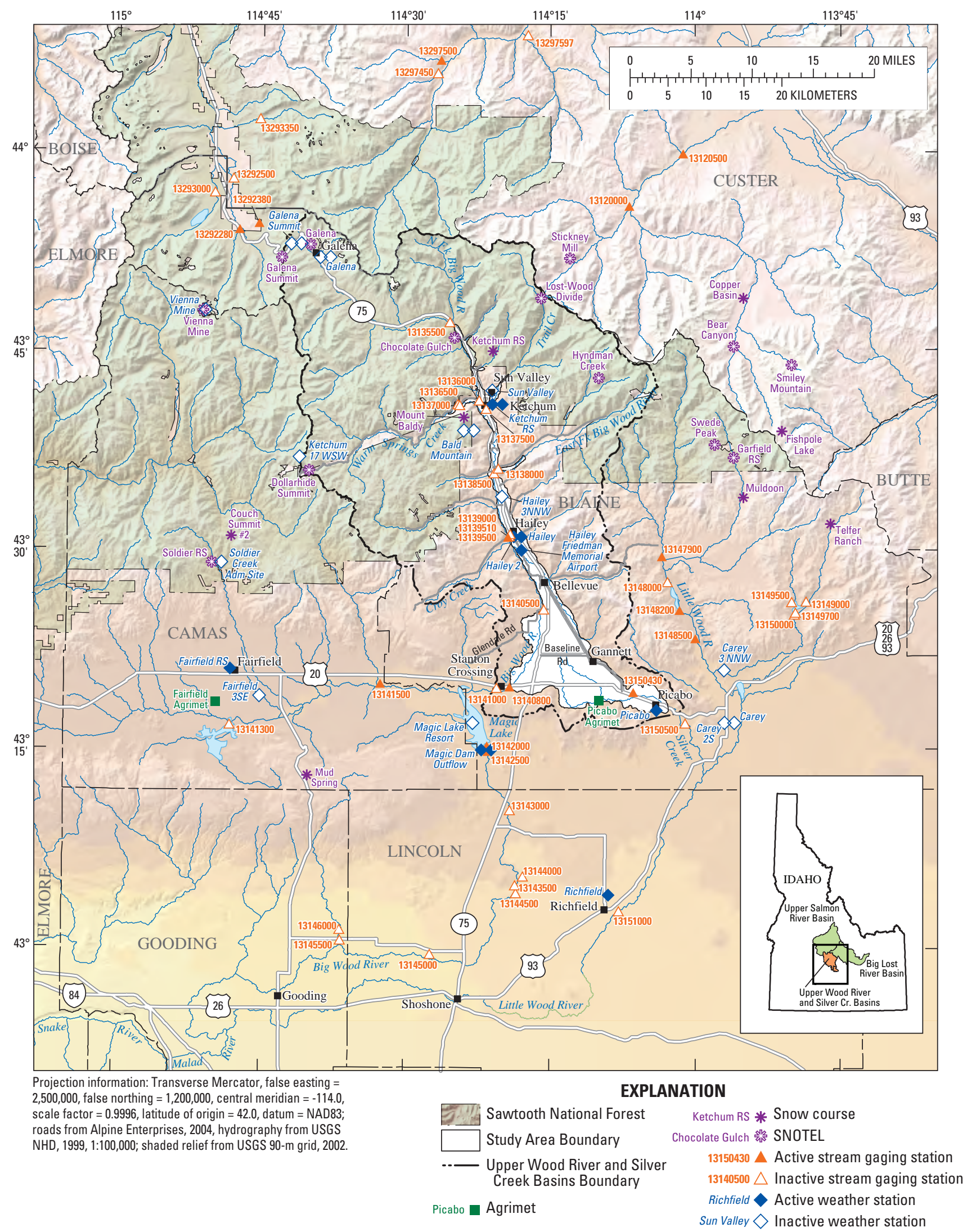

Figure 1. Location of communities, continuous streamflow-gaging stations, weather stations, and snow-survey sites, Wood River Valley, south-central Idaho. 


\section{Hydrogeologic Setting and Framework}

The Wood River Valley lies within the Northern Rocky Mountain physiographic province (Fenneman, 1931). Bedrock highlands of Precambrian metamorphic, Mesozoic sedimentary, and Tertiary intrusive and volcanic rocks surround the valley. The valley itself is filled with interbedded, Quaternary basalts and lacustrine, fluvial, and proglacial sediments deposited during late-Pleistocene glaciation. Sediments underlying the valley floor in the southern part of the Wood River Valley were largely deposited as an alluvial fan (the Bellevue fan) with the Big Wood River continually shifting and depositing sediment across its surface. Episodic volcanic activity disrupted the surface-water drainage pattern; after one such eruption created a lava dam, a lake formed over the Bellevue fan, depositing fine-grained lacustrine sediments. After the dam was breached, deposition of alluvial sediments continued until post-glacial climate change caused the Big Wood River to incise about $30 \mathrm{ft}$; resulting in its current appearance. However, glaciofluvial sediments deposited in the tributary canyons have been largely unaffected by the Holocene climate; thus they preserve their Pleistocene form. Schmidt (1962) provides a detailed discussion of the depositional history of the sediments that comprise the aquifer.

\section{Ground Water}

The aquifer system in the study area, which includes unconfined and confined aquifers, is comprised primarily of the Quaternary sediments of the Wood River Valley. Because the aquifer system is sufficiently productive at shallow depths, few wells in the main valley have been drilled through these deposits to bedrock. Cross sections by Moreland (1977) suggest that the thickness of the Quaternary deposits approach $500 \mathrm{ft}$ in places, however, in most of the study area the deposits are much thinner. In the vicinity of Ketchum, bedrock is at a depth of about $100 \mathrm{ft}$. Castelin and Winner (1975) performed a surficial geophysical survey across the Big Wood River canyon about 1 mi upstream of its confluence with the North Fork Big Wood River, and they concluded that bedrock was at a depth of 22-32 ft. Thickness of the unconsolidated sediment in the tributary canyons may be as little as $30 \mathrm{ft}$ in the Warm Springs Creek drainage. Schmidt (1962) noted that

"The thickness of the valley-bottom deposits averages about 8 feet where tested by drilling on lower Rock, Reed, and Brock Creeks."

The upper unconfined aquifer is present throughout the entire study area and lies directly on bedrock in the upper Wood River Valley and on Quaternary lacustrine deposits south of Baseline Road. Depth to water in the unconfined aquifer is commonly less than $10 \mathrm{ft}$ in the upper valley, increasing to about $90 \mathrm{ft}$ southward; in the lower valley they range from less than 10 to about $150 \mathrm{ft}$ below land surface.
The lower confined aquifer is only present south of Baseline Road and is separated from the overlying unconfined aquifer by fine-grained lacustrine deposits present at a depth of approximately $150 \mathrm{ft}$ (Moreland, 1977). These lacustrine sediments thicken toward the south thus creating a confining layer beneath which ground water is under confined conditions. In general, as land surface elevation decreases to the south the potentiometric surface rises above land surface and wells have the ability to flow under artesian pressure.

Locally (primarily in tributary canyons), the less permeable igneous, sedimentary, or metamorphic rocks that comprise the bedrock underlying the Quaternary sediments of the confined and unconfined aquifers provide water to wells either through hydraulic connection or through well completions directly in these rocks. Currently (2006) little is known about the water-bearing characteristics of these units because relatively few wells have been completed in them. As additional wells are drilled into these units and more information becomes available further assessment will be possible. However, some of these rocks are the source of water to the geothermal springs located on the west side of the Wood River Valley in tributary canyons (Street, 1990); consequently water quality may be poor.

Because the ground-water and surface-water systems are closely linked in the Wood River Valley, a ground-water level map alone cannot describe ground-water conditions. Additional information is required, such as locations of seepage to and from streams in the Wood River Valley.

Brockway and Grover (1978) used the terms "Big WoodSilver Creek aquifer system" and "Big Wood-Silver Creek aquifer" interchangeably in referring to the unconfined and confined aquifers within the valley fill, although they did not explicitly define either term. This nomenclature has not been used subsequently; instead the aquifer typically has been referred to by the hydrologic condition in a given location (confined or unconfined). Thus, for clarification, the aquifer system of the Wood River Valley is here informally named the Wood River Valley aquifer system. It includes the Quaternary sediments of the Wood River Valley and its tributaries and locally, underlying igneous, sedimentary, or metamorphic rocks where they are hydraulically connected and used for water supply. The Wood River Valley aquifer system is comprised of a single unconfined aquifer and an underlying confined aquifer present south of Baseline Road.

\section{Surface Water}

Most of the Wood River Valley is drained by the Big Wood River or its tributaries, except for the southeastern part of the Bellevue fan, which is drained by Silver Creek. The Big and Little Wood Rivers meet near Gooding, about $35 \mathrm{mi}$ southwest of the study area, where they become the Malad River, a tributary to the Snake River. The Big Wood River 
originates near Galena Summit, about 20 mi northwest of Ketchum, and it gains flow from a number of perennial and intermittent tributaries. It meanders across the narrow upper valley until Bellevue, where it flows along the western side of the Bellevue fan, finally exiting the valley at Stanton Crossing. Fed by springs and seeps, Silver Creek and its tributaries originate on the Bellevue fan and flows out of the valley at Picabo. Most of the tributary canyons to the Big Wood River are intermittent and flow only in response to precipitation or snowmelt, however, Trail Creek, North Fork Big Wood River, East Fork Big Wood River, Warm Springs Creek, Croy Creek, and Deer Creek typically flow into the Big Wood River yearround. Streams in some of the tributary canyons are perennial in their upper reaches-some of this flow likely infiltrates directly into the Wood River Valley aquifer system or reaches the Big Wood River by subsurface flow through streambed gravels. A network of irrigation canals and drains exists throughout the study area; most of the Wood River Valley was under irrigation by 1900 (Jones, 1952). The irrigation system complicates the interpretation of streamflow measurements on the Big Wood River because most of the numerous irrigation diversions and returns between stream gages are ungaged; seepage into and out of irrigation canals and ditches further affects such interpretation.
The USGS has operated 44 continuous-record streamflow-gaging stations within a 25 -mi buffer of the study area, including 9 stations in the Upper Salmon River basin and 2 stations in the Big Lost River basin; the remaining 33 stations are within the Wood River basin (fig. 1). Of these 44 stations, 13 were active in 2006 . Within or immediately adjacent to the study area itself there have been 13 stations, three of which were active in 2006: Big Wood River at Hailey (13139500), Big Wood River at Stanton Crossing near Bellevue (13140800), and Silver Creek at Sportsman Access near Picabo (13150430) (table 1). Of the 13 stations within the study area, 6 were operated only during water years 1920-21. Thus, only 7 stations have at least 10 years of streamflow data. Warm Springs Creek at Guyer Hot Springs near Ketchum (13136500) is the only tributary to the Big Wood River gaged for more than 2 years.

Differing periods of stream gage operation, along with irrigation diversions and returns, complicate the comparison of streamflow between gaging stations. For instance, the Big Wood River at Stanton Crossing near Bellevue gaging station (13140800) replaced the Big Wood River near Bellevue gaging station (13141000) in 1996, however, the two "are not equivalent because of inflow between sites" (Brennan and others, 2005). Thus, caution was exercised in comparing streamflow statistics for the 8 gaging stations with at least 10 years of streamflow data (table 2).

Table 1. Continuous record streamflow-gaging stations within a 25-mile buffer of Wood River Valley, south-central Idaho.

[Station numbers shown in bold type were evaluated for the study; -, not applicable]

\begin{tabular}{|c|c|c|c|c|}
\hline $\begin{array}{c}\text { Gaging } \\
\text { station No. }\end{array}$ & Gaging station name & Latitude & Longitude & $\begin{array}{l}\text { Period of record } \\
\text { (water years) }\end{array}$ \\
\hline 13120000 & North Fork Big Lost River at Wild Horse, near Chilly & $43^{\circ} 55^{\prime} 58^{\prime \prime} \mathrm{N}$ & $114^{\circ} 06^{\prime} 50^{\prime \prime} \mathrm{W}$ & 1944-present \\
\hline 13135500 & Big Wood River near Ketchum & $43^{\circ} 47^{\prime} 11^{\prime \prime} \mathrm{N}$ & $114^{\circ} 25^{\prime} 27^{\prime \prime} \mathrm{W}$ & $1948-72$ \\
\hline 13136000 & Big Wood River at Ketchum & $43^{\circ} 41^{\prime} 19^{\prime \prime} \mathrm{N}$ & $114^{\circ} 22^{\prime} 24^{\prime \prime} \mathrm{W}$ & $1920-21$ \\
\hline 13136500 & Warm Springs Creek at Guyer Hot Springs, near Ketchum & $43^{\circ} 41^{\prime} 00^{\prime \prime} \mathrm{N}$ & $114^{\circ} 24^{\prime} 37^{\prime \prime W}$ & $1941-58$ \\
\hline 13138000 & East Fork Big Wood River at Gimlet & $43^{\circ} 36^{\prime} 12^{\prime \prime} \mathrm{N}$ & $114^{\circ} 20^{\prime} 21^{\prime \prime} \mathrm{W}$ & $1920-21$ \\
\hline 13138500 & Big Wood River at Gimlet & $43^{\circ} 35^{\prime} 51^{\prime \prime} \mathrm{N}$ & $114^{\circ} 20^{\prime} 49^{\prime \prime} \mathrm{W}$ & $1920-21$ \\
\hline 13139000 & Big Wood Slough at Hailey & $43^{\circ} 31^{\prime} 05^{\prime \prime} \mathrm{N}$ & $114^{\circ} 19^{\prime} 12^{\prime \prime W}$ & $1915-74$ \\
\hline 13139500 & Big Wood River at Hailey & $43^{\circ} 31^{\prime} 02^{\prime \prime} \mathrm{N}$ & $114^{\circ} 19^{\prime} 18^{\prime \prime} \mathrm{W}$ & 1889, 1915-present \\
\hline $13139510^{1}$ & Combination Big Wood River/Slough at Hailey & $43^{\circ} 31^{\prime} 05^{\prime \prime} \mathrm{N}$ & $114^{\circ} 19^{\prime} 10^{\prime \prime} \mathrm{W}$ & - \\
\hline 13140500 & Big Wood River at Glendale Bridge, near Bellevue & $43^{\circ} 25^{\prime} 35^{\prime \prime} \mathrm{N}$ & $114^{\circ} 15^{\prime} 39^{\prime \prime} \mathrm{W}$ & $1920-21$ \\
\hline 13142000 & Magic Reservoir near Richfield & $43^{\circ} 15^{\prime} 19^{\prime \prime} \mathrm{N}$ & $114^{\circ} 21^{\prime} 29^{\prime \prime} \mathrm{W}$ & 1909-present \\
\hline
\end{tabular}


Table 1. Continuous record streamflow-gaging stations within a 25-mile buffer of Wood River Valley, south-central Idaho.-Continued

[Station numbers shown in bold type were evaluated for the study; -, not applicable]

\begin{tabular}{|c|c|c|c|c|}
\hline $\begin{array}{c}\text { Gaging } \\
\text { station No. }\end{array}$ & Gaging station name & Latitude & Longitude & $\begin{array}{l}\text { Period of record } \\
\text { (water years) }\end{array}$ \\
\hline 13142500 & Big Wood River below Magic Dam, near Richfield & $43^{\circ} 14^{\prime} 53^{\prime \prime} \mathrm{N}$ & $114^{\circ} 21^{\prime} 20^{\prime \prime} \mathrm{W}$ & 1911-present \\
\hline 13143500 & Lincoln Canal near Shoshone & $43^{\circ} 04^{\prime} 49.15^{\prime \prime} \mathrm{N}$ & $114^{\circ} 18^{\prime} 33.32^{\prime \prime} \mathrm{W}$ & $1925-48$ \\
\hline 13144000 & Big Wood River above North Gooding Canal near Shoshone & $43^{\circ} 05^{\prime} 27.54^{\prime \prime} \mathrm{N}$ & $114^{\circ} 17^{\prime} 46.19^{\prime \prime} \mathrm{W}$ & $1921-25,1927,1932-33,1938$ \\
\hline 13144500 & Big Wood River below North Gooding Canal near Shosone & $43^{\circ} 04^{\prime} 12.25^{\prime \prime} \mathrm{N}$ & $114^{\circ} 18^{\prime} 28.04^{\prime \prime} \mathrm{W}$ & $1921-28,1930,1932-33,1938$ \\
\hline 13146000 & Thorn Creek spillway near Gooding & $43^{\circ} 01 ' 27.17^{\prime \prime} \mathrm{N}$ & $114^{\circ} 36^{\prime} 34.16^{\prime \prime} \mathrm{W}$ & $1928-48$ \\
\hline 13147900 & Little Wood River at High Five Creek, near Carey & $43^{\circ} 29^{\prime} 30^{\prime \prime} \mathrm{N}$ & $114^{\circ} 03^{\prime} 30^{\prime \prime} \mathrm{W}$ & 1958-74, 1979-present \\
\hline 13148000 & Little Wood River at Campbell Ranch, near Carey & $43^{\circ} 27^{\prime} 40^{\prime \prime} \mathrm{N}$ & $114^{\circ} 02^{\prime} 50^{\prime \prime} \mathrm{W}$ & $\begin{array}{l}\text { 1920-26, 1937-38, 1941-43, } \\
\quad 1944-58\end{array}$ \\
\hline 13148200 & Little Wood River Reservoir, near Carey & $43^{\circ} 25^{\prime} 31^{\prime \prime} \mathrm{N}$ & $114^{\circ} 01^{\prime} 38^{\prime \prime} \mathrm{W}$ & 1955-present \\
\hline 13148500 & Little Wood River near Carey & $43^{\circ} 23^{\prime} 24^{\prime \prime} \mathrm{N}$ & $113^{\circ} 59^{\prime} 59^{\prime \prime} \mathrm{W}$ & $\begin{array}{l}\text { 1904-05, 1926-42, } \\
\text { 1943-present }\end{array}$ \\
\hline 13150000 & Fish Creek near Carey & $43^{\circ} 25^{\prime} 12^{\prime \prime} \mathrm{N}$ & $113^{\circ} 49^{\prime} 45^{\prime \prime} \mathrm{W}$ & 1919-20, 1923-39 \\
\hline 13151000 & Little Wood River near Richfield & $43^{\circ} 02^{\prime} 51.21^{\prime \prime} \mathrm{N}$ & $114^{\circ} 07^{\prime} 55.2^{\prime \prime} \mathrm{W}$ & $1911-73$ \\
\hline 13150430 & Silver Creek at Sportsman Access, near Picabo & $43^{\circ} 19^{\prime} 20^{\prime \prime} \mathrm{N}$ & $114^{\circ} 06^{\prime} 24^{\prime \prime W}$ & 1974-present \\
\hline 13150500 & Silver Creek at Highway 20, near Picabo & $43^{\circ} 17^{\prime} 01^{\prime \prime} \mathrm{N}$ & $114^{\circ} 01^{\prime} 04^{\prime \prime W}$ & $1920-62$ \\
\hline 13292280 & $\begin{array}{l}\text { Salmon River at Pole Creek Road, above diversions, } \\
\text { near Obsidian }\end{array}$ & $43^{\circ} 54^{\prime} 08^{\prime \prime} \mathrm{N}$ & $114^{\circ} 47^{\prime} 25^{\prime \prime} \mathrm{W}$ & 2003-present \\
\hline 13292380 & Pole Creek below Pole Creek Ranger Station, near Obsidian & $43^{\circ} 54^{\prime} 36^{\prime \prime} \mathrm{N}$ & $114^{\circ} 45^{\prime} 23^{\prime \prime} \mathrm{W}$ & 2003-present \\
\hline 13292500 & Salmon River above Lost Creek, near Obsidian & $43^{\circ} 57^{\prime} 57^{\prime \prime} \mathrm{N}$ & $114^{\circ} 48^{\prime} 01^{\prime \prime W}$ & $1941-53$ \\
\hline 13293000 & Alturas Lake Creek near Obsidian & $43^{\circ} 56^{\prime} 55^{\prime \prime} \mathrm{N}$ & $114^{\circ} 50^{\prime} 00^{\prime \prime} \mathrm{W}$ & $1941-52$ \\
\hline 13293350 & Fourth of July Creek above diversions, near Obsidian & $44^{\circ} 02^{\prime} 26^{\prime \prime} \mathrm{N}$ & $114^{\circ} 45^{\prime} 21^{\prime \prime W}$ & 2003-04 \\
\hline 13297450 & Little Boulder Creek near Clayton & $44^{\circ} 05^{\prime} 57^{\prime \prime} \mathrm{N}$ & $114^{\circ} 26^{\prime} 50^{\prime \prime} \mathrm{W}$ & $1970-86$ \\
\hline
\end{tabular}

${ }^{1}$ This station was renamed Big Wood River at Hailey (13139500).

Table 2. Mean annual and annual peak flow from selected streamflow-gaging stations in and adjacent to Wood River Valley, southcentral Idaho.

[Location of gaging stations is shown in figure 1 . Abbreviations: $\mathrm{ft}^{3} / \mathrm{s}$, cubic foot per second]

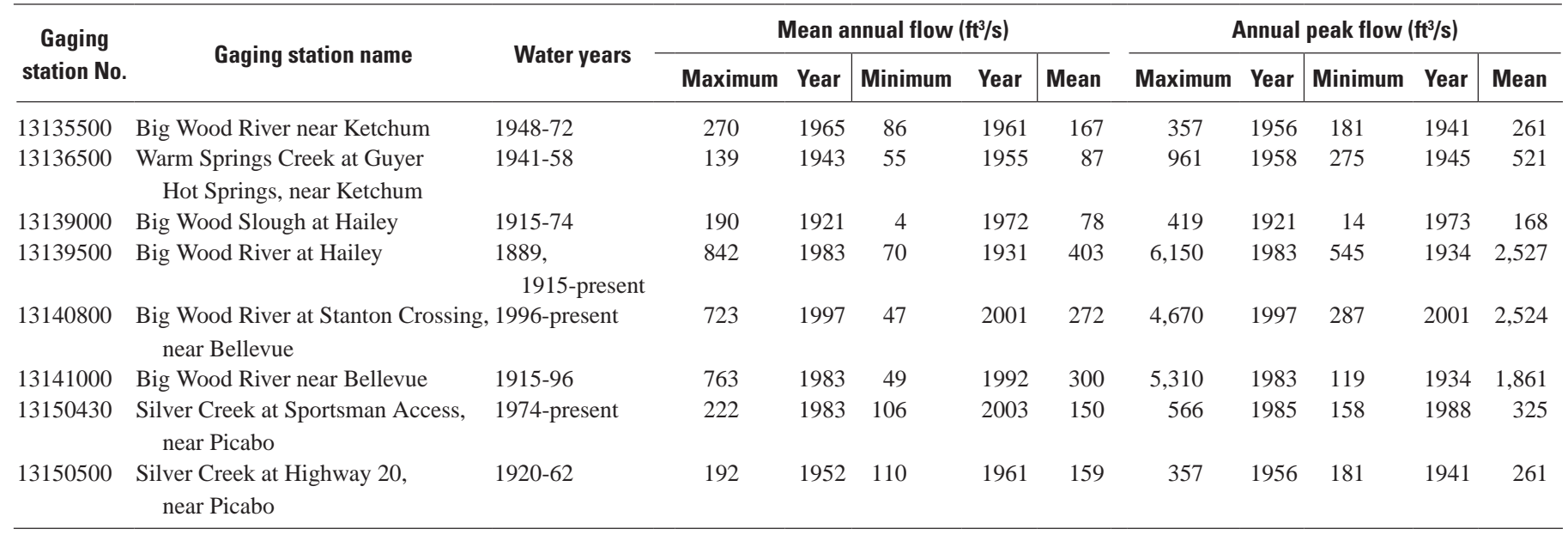




\section{Climate}

The Wood River Valley has a mild, arid climate during the summer months, but cold, wet conditions in the winter. About 60 percent of the total annual precipitation falls between the first of November and the end of March mostly as snow. The growing season in the study area varies widely with elevation, ranging from about 3 months at Sun Valley to about 5 months in the lower valley.

The entire study area is classified as Dsb under a modified Köppen system in which $D$ indicates a mean temperature of the warmest month greater than $10^{\circ} \mathrm{C}\left(40^{\circ} \mathrm{F}\right)$ and a mean temperature of the coldest month $0^{\circ} \mathrm{C}\left(32^{\circ} \mathrm{F}\right)$ or below; Sindicates that precipitation in the driest month is less than $1.6 \mathrm{in} .(40 \mathrm{~mm})$ and less than one-third of the amount in the wettest month; and bindicates that the mean temperature of each of the four warmest months is $10^{\circ} \mathrm{C}\left(40^{\circ} \mathrm{F}\right)$ or greater and the mean temperature of the warmest month is below $22^{\circ} \mathrm{C}\left(72^{\circ} \mathrm{F}\right)$ (Critchfield, 1983; Godfrey, 2000).

The National Weather Service (NWS) has 21 weather stations within a 25-mi buffer of the study area, although only 8 are active (table 3 , fig. 1). Of these 8 stations, only 2 are within or immediately adjacent to the study area and have sufficient long-term data for climatic calculations: Ketchum Ranger Station and Picabo. As of 2006, there were two active AgriMet stations located in or within $25 \mathrm{mi}$ of the study area: Picabo, Idaho (PICI) and Fairfield, Idaho (FAFI) (Bureau of Reclamation, 2006). In addition, 21 active Natural Resources Conservation Service snow-survey sites are located in or within $25 \mathrm{mi}$ of the study area; 13 of these are instrumented SNOTEL sites and 8 are snow courses (Natural Resources Conservation Service, 2006).

Table 3. National Weather Service stations, AgriMet stations, and snow-survey sites in or near the Wood River Valley, south-central Idaho.

[Western Regional Climate Center (2006); Bureau of Reclamation (2006); Natural Resources Conservation Service (2006); Abbreviations: NWS, National Weather Service; RS, Ranger Station; -, to be measured in 2007; **, unknown]

\begin{tabular}{|c|c|c|c|c|c|c|}
\hline \multirow{2}{*}{ Station name } & \multirow{2}{*}{$\begin{array}{c}\text { Station or } \\
\text { identification No. }\end{array}$} & \multirow{2}{*}{$\begin{array}{c}\text { Elevation } \\
\text { (feet above } \\
\text { sea level) }\end{array}$} & \multirow{2}{*}{ Latitude } & \multirow{2}{*}{ Longitude } & \multicolumn{2}{|c|}{ Dates in operation } \\
\hline & & & & & Starting date & Ending date \\
\hline \multicolumn{7}{|c|}{ NWS stations } \\
\hline Bald Mountain & 100540 & 8,701 & $43^{\circ} 39^{\prime} \mathrm{N}$ & $114^{\circ} 24^{\prime} \mathrm{W}$ & $12-01-53$ & $02-17-77$ \\
\hline Carey & 101472 & 4,783 & $43^{\circ} 17^{\prime} \mathrm{N}$ & $113^{\circ} 56^{\prime} \mathrm{W}$ & $09-01-68$ & $11-13-84$ \\
\hline Carey $2 \mathrm{~S}$ & 101461 & 4,764 & $43^{\circ} 17^{\prime} \mathrm{N}$ & $113^{\circ} 57^{\prime} \mathrm{W}$ & $07-01-56$ & $04-30-58$ \\
\hline Carey 3 NNW & 101466 & 4,843 & $43^{\circ} 21^{\prime} \mathrm{N}$ & $113^{\circ} 57^{\prime} \mathrm{W}$ & $10-23-62$ & $09-20-68$ \\
\hline Fairfield 3SE & 103110 & 5,020 & $43^{\circ} 19^{\prime} \mathrm{N}$ & $114^{\circ} 45^{\prime} \mathrm{W}$ & $10-01-78$ & 08-19-98 \\
\hline Fairfield RS & 103108 & 5,070 & $43^{\circ} 21^{\prime} \mathrm{N}$ & $114^{\circ} 48^{\prime} \mathrm{W}$ & $10-01-48$ & - \\
\hline Galena Summit & 103422 & 8,806 & $43^{\circ} 53^{\prime} \mathrm{N}$ & $114^{\circ} 42^{\prime} \mathrm{W}$ & $09-01-63$ & $09-30-76$ \\
\hline Galena & 103417 & 7,300 & $43^{\circ} 52^{\prime} \mathrm{N}$ & $114^{\circ} 39^{\prime} \mathrm{W}$ & $09-01-63$ & $03-31-96$ \\
\hline Hailey & 103940 & 5,312 & $43^{\circ} 31^{\prime} \mathrm{N}$ & $114^{\circ} 18^{\prime} \mathrm{W}$ & $01-12-05$ & - \\
\hline Hailey 2 & 103947 & 5,295 & $43^{\circ} 31^{\prime} \mathrm{N}$ & $114^{\circ} 19^{\prime} \mathrm{W}$ & $03-01-66$ & - \\
\hline Hailey 3NNW & 103942 & 5,420 & $43^{\circ} 34^{\prime} \mathrm{N}$ & $114^{\circ} 20^{\prime} \mathrm{W}$ & $08-01-48$ & $11-31-88$ \\
\hline Hailey Friedman Memorial Airport & 94161 & 5,306 & $43^{\circ} 30^{\prime} \mathrm{N}$ & $114^{\circ} 18^{\prime} \mathrm{W}$ & $06-01-53$ & - \\
\hline Ketchum 17 WSW & 104840 & 8,425 & $43^{\circ} 37^{\prime} \mathrm{N}$ & $114^{\circ} 41^{\prime} \mathrm{W}$ & $08-01-54$ & $03-31-75$ \\
\hline Ketchum RS & 104845 & 5,890 & $43^{\circ} 41^{\prime} \mathrm{N}$ & $114^{\circ} 21^{\prime} \mathrm{W}$ & $05-01-73$ & - \\
\hline Magic Dam Outflow & 105513 & 4,665 & $43^{\circ} 15^{\prime} \mathrm{N}$ & $114^{\circ} 22^{\prime} \mathrm{W}$ & $08-01-76$ & - \\
\hline Magic Lake Resort & 105510 & 4,803 & $43^{\circ} 17^{\prime} \mathrm{N}$ & $114^{\circ} 23^{\prime} \mathrm{W}$ & $06-01-66$ & $10-10-75$ \\
\hline Picabo & 107040 & 4,880 & $43^{\circ} 18^{\prime} \mathrm{N}$ & $114^{\circ} 04^{\prime} \mathrm{W}$ & $04-22-58$ & - \\
\hline Richfield & 107673 & 4,310 & $43^{\circ} 04^{\prime} \mathrm{N}$ & $114^{\circ} 09^{\prime} \mathrm{W}$ & $08-01-48$ & - \\
\hline Sun Valley & 108906 & 5,980 & $43^{\circ} 42^{\prime} \mathrm{N}$ & $114^{\circ} 21^{\prime} \mathrm{W}$ & $08-01-48$ & $12-31-72$ \\
\hline \multicolumn{7}{|c|}{ AgriMet stations } \\
\hline Picabo & PICI & 4,900 & $43^{\circ} 19^{\prime} \mathrm{N}$ & $114^{\circ} 10^{\prime} \mathrm{W}$ & $04-21-93$ & - \\
\hline Fairfield & FAFI & 5,038 & $43^{\circ} 18^{\prime} \mathrm{N}$ & $114^{\circ} 50^{\prime} \mathrm{W}$ & $06-25-87$ & - \\
\hline
\end{tabular}


Table 3. National Weather Service stations, AgriMet stations, and snow-survey sites in or near the Wood River Valley, south-central Idaho.-Continued.

[Western Regional Climate Center (2006); Bureau of Reclamation (2006); Natural Resources Conservation Service (2006); Abbreviations: NWS, National Weather Service; RS, Ranger Station; -, to be measured in 2007; **, unknown]

\begin{tabular}{|c|c|c|c|c|c|c|}
\hline \multirow[b]{2}{*}{ Station name } & \multirow{2}{*}{$\begin{array}{c}\text { Station or } \\
\text { identification No. }\end{array}$} & \multirow{2}{*}{$\begin{array}{c}\text { Elevation } \\
\text { (feet above } \\
\text { sea level) }\end{array}$} & \multirow[b]{2}{*}{ Latitude } & \multirow[b]{2}{*}{ Longitude } & \multicolumn{2}{|c|}{ Dates in operation } \\
\hline & & & & & Starting date & Ending date \\
\hline \multicolumn{7}{|c|}{ Snow survey sites } \\
\hline Chocolate Gulch $^{1}$ & $14 \mathrm{~F} 19 \mathrm{~s}$ & 6,440 & $43^{\circ} 46^{\prime} \mathrm{N}$ & $114^{\circ} 25^{\prime} \mathrm{W}$ & 1994 & - \\
\hline Couch Summit \#22 & 14F18 & 6,840 & $43^{\circ} 31^{\prime} \mathrm{N}$ & $114^{\circ} 48^{\prime} \mathrm{W}$ & 1961 & - \\
\hline Dollarhide Summit ${ }^{1}$ & 14F08s & 8,420 & $43^{\circ} 36^{\prime} \mathrm{N}$ & $114^{\circ} 40^{\prime} \mathrm{W}$ & 1982 & - \\
\hline Galena $^{1}$ & $14 \mathrm{~F} 17 \mathrm{~s}$ & 7,470 & $43^{\circ} 53^{\prime} \mathrm{N}$ & $114^{\circ} 40^{\prime} \mathrm{W}$ & 1982 & - \\
\hline Galena Summit $^{1}$ & $14 \mathrm{~F} 12 \mathrm{~s}$ & 8,780 & $43^{\circ} 52^{\prime} \mathrm{N}$ & $114^{\circ} 43^{\prime} \mathrm{W}$ & 1982 & - \\
\hline Garfield RS ${ }^{1}$ & $13 \mathrm{~F} 04 \mathrm{~s}$ & 6,560 & $43^{\circ} 37^{\prime} \mathrm{N}$ & $113^{\circ} 56^{\prime} \mathrm{W}$ & 1981 & - \\
\hline Hyndman Creek ${ }^{1}$ & 14F16s & 7,440 & $43^{\circ} 43^{\prime} \mathrm{N}$ & $114^{\circ} 10^{\prime} \mathrm{W}$ & 1981 & - \\
\hline Ketchum RS ${ }^{2}$ & $14 \mathrm{~F} 21$ & 5,890 & $43^{\circ} 45^{\prime} \mathrm{N}$ & $114^{\circ} 21^{\prime} \mathrm{W}$ & $* *$ & - \\
\hline Lost-Wood Divide $^{1}$ & $14 \mathrm{~F} 03 \mathrm{~s}$ & 7,900 & $43^{\circ} 49^{\prime} \mathrm{N}$ & $114^{\circ} 16^{\prime} \mathrm{W}$ & 1982 & - \\
\hline Mount Baldy $^{2}$ & 14F09 & 8,900 & $43^{\circ} 40^{\prime} \mathrm{N}$ & $114^{\circ} 24^{\prime} \mathrm{W}$ & 1949 & - \\
\hline Muldoon $^{2}$ & $13 \mathrm{~F} 05$ & 6,320 & $43^{\circ} 34^{\prime} \mathrm{N}$ & $113^{\circ} 55^{\prime} \mathrm{W}$ & 1953 & - \\
\hline Soldier RS ${ }^{1}$ & 14F11s & 5,740 & $43^{\circ} 29^{\prime} \mathrm{N}$ & $114^{\circ} 50^{\prime} \mathrm{W}$ & 1987 & - \\
\hline Stickney Mill ${ }^{1}$ & $14 \mathrm{~F} 02 \mathrm{~s}$ & 7,430 & $43^{\circ} 52^{\prime} \mathrm{N}$ & $114^{\circ} 13^{\prime} \mathrm{W}$ & 1981 & - \\
\hline Swede Peak ${ }^{1}$ & $13 \mathrm{~F} 09 \mathrm{~s}$ & 7,640 & $43^{\circ} 38^{\prime} \mathrm{N}$ & $113^{\circ} 58^{\prime} \mathrm{W}$ & 1982 & - \\
\hline Vienna Mine $^{1}$ & $14 \mathrm{~F} 04 \mathrm{~s}$ & 8,960 & $43^{\circ} 48^{\prime} \mathrm{N}$ & $114^{\circ} 51^{\prime} \mathrm{W}$ & 1981 & - \\
\hline
\end{tabular}

${ }^{1}$ SNOTEL site.

${ }^{2}$ Snow-course site.

Eight active and inactive NWS stations provide sufficient data for calculation of long-term means (table 4). The remaining 13 stations were not included because of partial, missing, or incomplete data or because only precipitation data were collected. Mean annual air temperatures at the 8 included stations range from $35.0^{\circ} \mathrm{F}$ at Galena to $45.6^{\circ} \mathrm{F}$ at Richfield (table 4). The coldest month in the area is January, with mean low air temperatures ranging from $0.3^{\circ} \mathrm{F}$ at Sun Valley to $13.2^{\circ} \mathrm{F}$ at Richfield. The warmest month typically is July, with mean high air temperatures ranging from $76.3^{\circ} \mathrm{F}$ at Galena to $87.1^{\circ} \mathrm{F}$ at Richfield. Mean first-freeze dates range from August 21 at Galena to October 15 at Richfield; mean last-freeze dates range from July 1 at Galena to April 27 at Richfield. Mean annual precipitation ranges from 11 in. at Richfield to about 25 in. at Galena. July and August typically are the driest months; December and January are the wettest. The greatest snow depth typically is in February, ranging from 7 in. at Richfield to 45 in. at Galena (Western Regional Climate Center, 2006.)

In December 1972, the Sun Valley station was discontinued; data collection was begun at the Ketchum Ranger Station in May 1973 (table 3). For the statistical analysis of trends described in section, "Ground-Water Level Trends," precipitation from these two stations was combined to create a continuous series dating from 1948 to 2006. The NWS follows this practice in precipitation data retrieved from the National Climatic Data Center.
Although drought can be defined in many different ways (meteorological, hydrological, or agricultural), one measure used to quantify drought is the Palmer Drought Severity Index (PDSI), a measure of long-term drought that uses precipitation, temperature, soil moisture, and other factors. The index accounts for long-term trends to define wet and dry periods, thus limiting its use in the most recent record. The PDSI uses zero as normal, negative numbers to represent drought, and positive numbers to represent abovenormal precipitation. The National Climatic Data Center calculates the PDSI (and other drought indices) for States by climate division; most of the Wood River Valley is within Idaho climate zone 4 (or Central Mountains division; U.S. Department of Commerce, 2006). The PDSI for Idaho climate zone 4 from January 1900 through October 2006 is shown in figure 2. The 241 months between October 1986 and October 2006, are characterized by two long periods of drier than normal conditions interrupted by four periods of wetter than normal conditions. Of these 241 months, 14 had PDSI values less than -0.5 and greater or equal to -1 , indicating drier than normal conditions, 158 experienced mild to extreme drought conditions (less than -1), and 53 months experienced slightly to very wet conditions (greater than 0.5 ) with the remaining months in the normal range. The range of PDSI values is 3.69 (January 1997) to -4.89 (February 1988). The average PDSI value for these 241 months is -1.58 . 
Table 4. Summary of data from selected weather stations in and near the Wood River Valley, south-central Idaho.

[Western Regional Climate Center (2006). Summary values are through December 31, 2005, for active stations. Abbreviations: ${ }^{\circ} \mathrm{F}$, degree Fahrenheit; in., inches; max., maximum, min., minimum; RS, Ranger Station; *, inactive station]

\begin{tabular}{|c|c|c|c|c|c|c|c|c|c|}
\hline \multirow{2}{*}{ Station name } & \multirow{2}{*}{$\begin{array}{l}\text { Mean July } \\
\text { maximum } \\
\text { air } \\
\text { temperature } \\
\left.\text { ( }{ }^{\circ} \mathrm{F}\right)\end{array}$} & \multicolumn{2}{|c|}{$\begin{array}{c}\text { Mean January } \\
\text { air temperature }\left({ }^{\circ} \mathrm{F}\right)\end{array}$} & \multirow{2}{*}{$\begin{array}{l}\text { Mean } \\
\text { annual air } \\
\text { temper- } \\
\text { ature } \\
\left({ }^{\circ} \mathrm{F}\right)\end{array}$} & \multirow{2}{*}{$\begin{array}{l}\text { Mean } \\
\text { annual } \\
\text { precipi- } \\
\text { tation } \\
\text { (in.) }\end{array}$} & \multirow{2}{*}{$\begin{array}{c}\text { Mean } \\
\text { annual } \\
\text { snowfall } \\
\text { (in.) }\end{array}$} & \multirow{2}{*}{$\begin{array}{l}\text { Mean } \\
\text { February } \\
\text { snow } \\
\text { depth } \\
\text { (in.) }\end{array}$} & \multicolumn{2}{|c|}{ Mean freeze date } \\
\hline & & Minimum & Maximum & & & & & Last & First \\
\hline Fairfield 3SE * & 82.3 & 1.9 & 27.7 & 39.9 & 12.6 & 50.8 & 14 & $05-11-06$ & 09-19-06 \\
\hline Fairfield RS & 85.5 & 5.1 & 28.9 & 41.5 & 15.0 & 69.8 & 19 & $05-05-06$ & $09-22-06$ \\
\hline Galena * & 76.3 & 4.4 & 31.6 & 35.0 & 24.7 & 183 & 45 & 07-01-06 & $08-21-06$ \\
\hline Hailey $3 \mathrm{NNW} *$ & 84.8 & 7.8 & 30.2 & 43.0 & 15.9 & 81.1 & 23 & 05-03-06 & $10-13-06$ \\
\hline Ketchum RS & 80.2 & 5.5 & 31.2 & 39.5 & 18.5 & 114 & 27 & $05-22-06$ & 09-20-06 \\
\hline Picabo & 86.3 & 7.5 & 30.9 & 42.6 & 12.9 & 42.9 & 8 & $05-05-06$ & $10-03-06$ \\
\hline Richfield & 87.1 & 13.2 & 30.8 & 45.6 & 11.0 & 32.4 & 7 & $04-27-06$ & $10-15-06$ \\
\hline Sun Valley * & 82.5 & .3 & 30.0 & 38.0 & 17.3 & 121 & 29 & $05-31-06$ & 09-03-06 \\
\hline
\end{tabular}

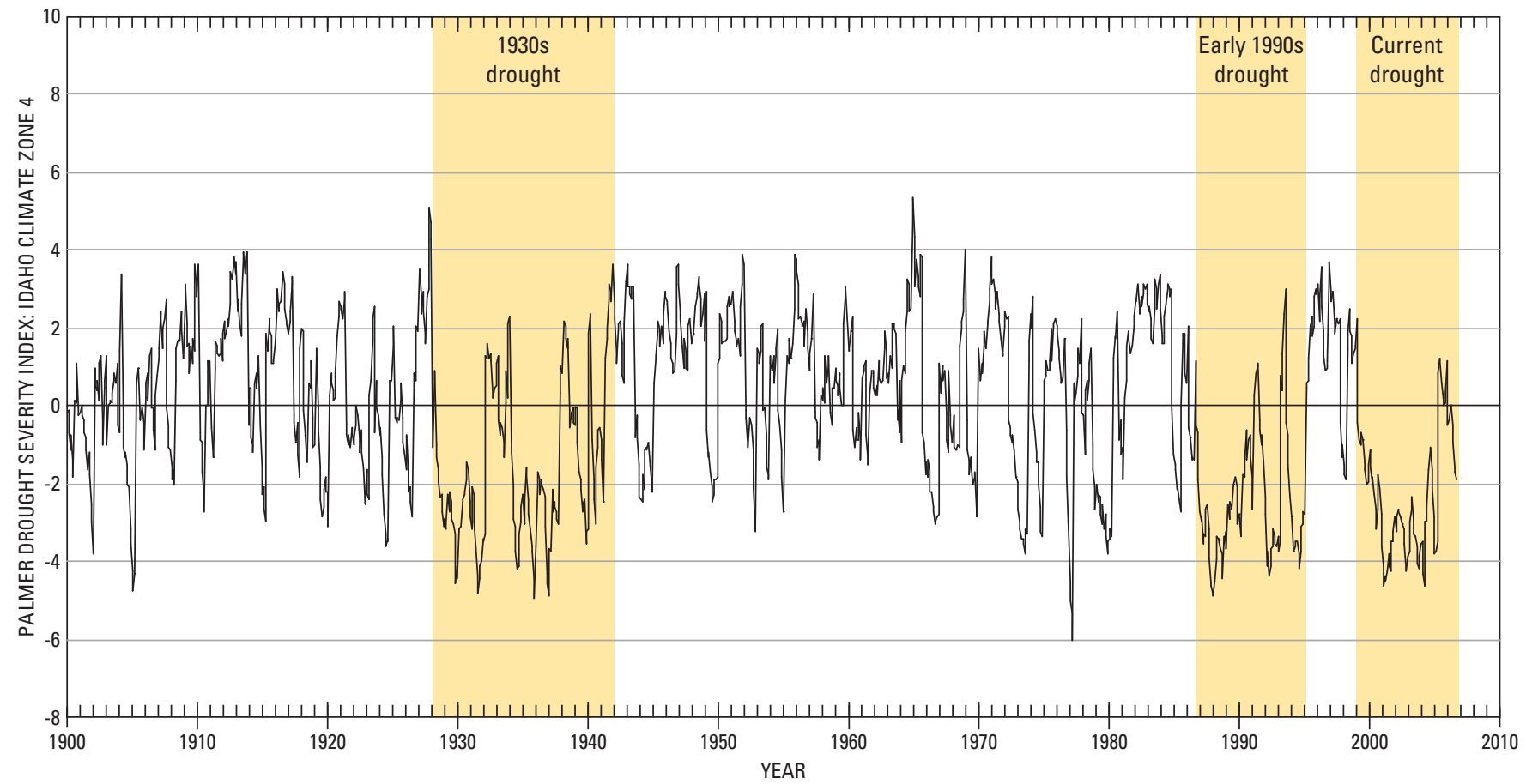

EXPLANATION

PALMER DROUGHT SEVERITY INDEX (PDSI) VALUE

-4 or less: Extreme drought

-4 to -3 : Severe drought

-3 to -2 : Moderate drought

-2 to -1 : Mild drought
-1 to -0.5 : Incipient dry spell

-0.5 to 0.5 : Near normal

0.5 to 1 : Incipient wet spell
1 to 2 : Slightly wet

2 to 3 : Moderately wet

3 to 4: Very wet

4 or more: Extremely wet

Figure 2. Palmer drought severity index for Idaho climate zone 4. 
When the 92 months from March 1999 through October 2006, the current drought, are compared to the PDSI values for the 20th century, they are matched in duration and severity by only the well-known drought of the 1930s (fig. 2). The 1930s drought consisted of three periods of drier than normal conditions and two periods of wetter than normal conditions. For the 14-year period between 1928 and 1941 (168 months), the PDSI was less than -0.5 and greater or equal to -1 for 9 months and 109 months were less than -1 . Twenty-three months were greater than 0.5 with the remaining 27 months were in the normal range.

\section{Population}

The population in the study area was about 15,000 in 2000 (census tracts 9601, 9602, and 9603), which is about 78 percent of the population of Blaine County (U.S. Census Bureau, 2006). The population of Blaine County increased about 11.5 percent between April 1, 2000 and July 1, 2005 as compared to a growth rate of 10.4 percent for the State of Idaho as a whole (U.S. Census Bureau, 2007). Campbell (1996) forecast the total population of Idaho to increase between 20 and 40 percent between 2005 and 2025 .

Because tract level census data for Blaine County does not exist for much of the 20th century, total population in Blaine County was used to show population growth by decennial census for 1900-2005 in figure 3 (Forstall, 1995; U.S. Census Bureau, 2007). These data show a relatively stable Blaine County population through 1970 and hence a relatively stable period of water withdrawal and consumption although water use for mining, power generation, and irrigation may have varied. This period is considered to represent predevelopment conditions. Population then rapidly increased after 1970, with a 171-percent increase between 1970 and 1980. This figure accounts for 27 percent of the total population growth between 1970 and 2005. The largest increase in population occurred between 1990 and 2000. This report considers the time period up to the mid-1980s to be partial-development before the continuing development of the Wood River Valley through 2005.

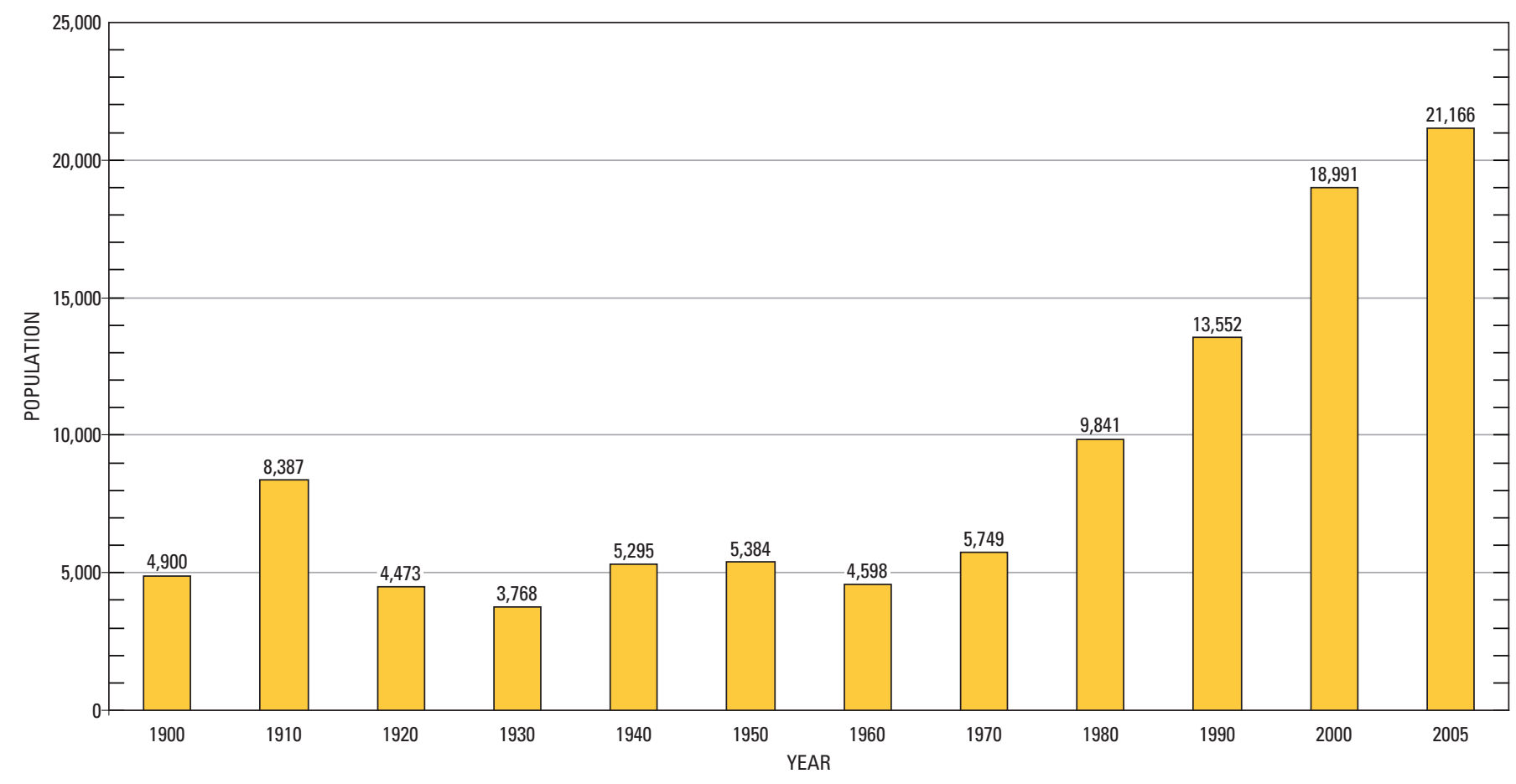

Figure 3. Blaine County population by decennial census, 1900-2000, and projected 2005 population, south-central Idaho 


\section{Methods and Data Sources}

\section{Ground-Water Level Trend Analysis}

Water levels were measured semi-annually in three wells in the Wood River Valley for more than 50 years. Mean annual water levels in these wells were evaluated with the nonparametric Mann-Kendall test to determine any statistically significant trends in water levels. If the Kendall's S statistic is significantly different from zero, it may be concluded that there is a monotonic trend in water levels over time. Temporal trends in ground-water levels were considered to be statistically significant if the confidence level was at least 99.5 percent and the $\mathrm{p}$-value (or level of significance) was less than 0.005. A detailed discussion of this technique is given in Helsel and Hirsch (1992).

Mean annual depth to water and total annual precipitation at the Ketchum Ranger Station were normalized using equations 1 and 2 to allow direct comparison between the two datasets in a plot.

$$
\begin{gathered}
d_{i}=y_{i}-\bar{y}, \\
N=\frac{d_{i}}{|D|},
\end{gathered}
$$

where $d_{i}$ equals the sample deviation of $i$,

$y_{i}$ is the sample $i$ in the series of $n$ samples,

$y$ is the mean of $n$ samples,

$N$ is the normalized value of sample $i$,

$d_{i}$ is the sample deviation of sample $i$, and

$|D|$ is the maximum absolute value of $d$ in the series.

\section{Streamflow Trend Analysis}

Long-term trend analysis was performed on three gaging stations in the Wood River Valley that have at least 20 years of record. Mean annual and monthly streamflow trends were analyzed, as well as 7-day and 30-day low-flow values for the period of record. The Base Flow Index (BFI), derived by a systematic method of calculating the volume of base flow for annual data, also was analyzed for any statistically significant trends. Long-term trends in precipitation and temperature were determined and were compared with streamflow data to account for anomalies.

Kendall's tau was used to test for a significant trend for all of the flow statistics with all of the p-values provided in table 5. In addition, the magnitude of the trend was estimated using Sen's Estimate of Slope, also provided in table 5. The Kendall's tau nonparametric hypothesis test measures monotonic correlation strength between two datasets (Helsel and Hirsch, 1992). In these cases, the two datasets are the flow statistic (mean annual and monthly discharge, 7- and 30-day low-flow values, and the BFI) and time. A strong relation between data sets indicates an increase or decrease in flow over time. The calculated $p$-value is the probability that the null hypothesis (no trend in data) is in fact true; thus statistical significance increases as $\mathrm{p}$-values decrease. Surface-water trends were judged statistically significant at the 90 -percent confidence level.

The 7- and 30-day low-flow statistics were calculated using a process that combines the U.S. Environmental Protection Agency (USEPA) BASINS program (Aquaterra Consultants, 2006; U.S. Environmental Protection Agency, 2006), S-Plus statistical software (Insightful Corp., 2005), and the USGS statistical library for S-Plus. This process calculates the annual low flow from the minimum value of an $n$-day moving average of daily streamflow. The annual minima are then plotted over the period of record to identify long-term trends for that site.

The BFI is calculated as the ratio of the volume of base flow to the volume of total flow for a given time period. It was developed by the Institute of Hydrology of the United Kingdom (1980a, 1980b) in an attempt to standardize baseflow calculations for reproducibility. This method was further improved and automated by Wahl and Wahl (1988) for use on unregulated streams in the United States. Traditional calculations originally developed for this application are based on a 5-day interval local minima slope estimate. For this study, a longer duration interval was used to account for large spring runoff events in the snowmelt-dominated streams of the Wood River Valley that typically occur over a several week period.

BFI calculations are made by an algorithm that identifies local hydrograph minima at a user-defined interval. As initially developed for rainfall-dominated basins in the United Kingdom and Midwestern United States, the interval was taken at 5 days. Turning points are calculated by a threepoint linear regression when a user-defined threshold slope is exceeded, commonly taken as 10-percent difference. The baseflow hydrograph is then created by connecting the turning points and integrating the area below the line.

The BFI calculations for the Big Wood River at Hailey gaging station data (13139510) were based on a 30-day interval over a year to identify base flow of a snowmeltdriven system as opposed to one dominated by rainfall. The Big Wood River near Bellevue (13141000) gage data used a 40-day interval for the BFI calculation and the Silver Creek at Sportsman Access (13150430) gage data used a 5-day interval. A shorter interval period, such as the default 5-day period, will introduce "false peaks" during springtime flows from melting snowpack for the Big Wood River gages. Although these longer intervals may lead to slight underestimation of base flow for the increased springtime runoff, it provides a consistent and reproducible approach for the analysis of longterm datasets. 


\section{Water-Resource Trends and Comparisons, Wood River Valley, South-Central Idaho}

Table 5. Surface-water trend analyses for three streamflow-gaging stations, Wood River Valley, south-central Idaho.

[All p-values are derived from Kendall's tau with the Sen slope estimator. Numbers in bold are greater than 90 percent statistically significant. Slopes with negative values represent declining trends and positive values show increasing trends]

\begin{tabular}{|c|c|c|c|c|c|c|c|c|c|c|c|c|c|}
\hline \multicolumn{5}{|l|}{ Annual trends } & & & & & & & & & \\
\hline \multirow{2}{*}{\multicolumn{2}{|c|}{$\begin{array}{l}\text { Big Wood River at Hailey Total } \\
\text { Big Wood River near Bellevue } \\
\text { Silver Creek at Sportsman Access }\end{array}$}} & 0.601 & \multicolumn{2}{|c|}{0.339} & & & & & & & & & \\
\hline & & .018 & \multicolumn{2}{|c|}{-1.627} & & & & & & & & & \\
\hline Gaging station & & Jan. & Feb. & Mar. & Apr. & May & June & July & Aug. & Sept. & Oct. & Nov. & Dec. \\
\hline \multirow{2}{*}{$\begin{array}{l}\text { Big Wood River at } \\
\text { Hailey Total }\end{array}$} & $p$-value & 0.123 & 0.183 & 0.006 & 0.845 & 0.864 & 0.626 & 0.626 & 0.237 & 0.194 & 0.268 & 0.219 & 0.663 \\
\hline & Slope & .216 & .175 & .538 & .180 & .444 & 2.000 & .704 & .543 & .431 & .311 & .253 & .079 \\
\hline $\begin{array}{l}\text { Big Wood River near } \\
\text { Bellevue }\end{array}$ & p-value & .006 & .095 & .908 & .773 & .941 & .337 & .494 & .458 & .615 & .221 & .223 & .014 \\
\hline $\begin{array}{l}\text { Silver Creek at } \\
\text { Sportsman Access }\end{array}$ & Slope & -1.167 & -1.332 & -.700 & -1.792 & -.200 & -.895 & -2.043 & -2.407 & -3.200 & -3.987 & -2.523 & -1.867 \\
\hline
\end{tabular}

\section{Low-flow trends}

\begin{tabular}{llrr}
\hline \multicolumn{1}{c}{ Gaging station } & \multicolumn{1}{c}{ Period } & $\boldsymbol{p}$-value & Slope \\
\hline Big Wood River at Hailey Total & 7-day & 0.117 & 0.001 \\
& 30-day & $\mathbf{. 0 9 7}$ & .001 \\
Big Wood River near Bellevue & 7-day & $\mathbf{. 0 8 4}$ & -.263 \\
& 30-day & $\mathbf{. 0 7 6}$ & -.319 \\
Silver Creek at Sportsman Access & 7-day & $\mathbf{. 0 7 4}$ & -.875 \\
& 30-day & .101 & -.897 \\
\hline
\end{tabular}

\section{BFI annual trends}

\begin{tabular}{lrr}
\hline \multicolumn{1}{c}{ Gaging station } & p-value & Slope \\
\hline Big Wood River at Hailey Total & 0.200 & 0.001 \\
Big Wood River near Bellevue & .905 & .000 \\
Silver Creek at Sportsman Access & .184 & -.170 \\
\hline
\end{tabular}




\section{Ground-Water Levels}

To estimate water-level changes in the Wood River Valley aquifer system between historic and current conditions (2006), one map representing each set of conditions was needed. Historic or predevelopment conditions refer to the period before 1970 with a relatively stable population (fig. 3), water withdrawals, and consumption. However, this study uses ground-water level data from 1970 to1986 to fill spatial data gaps in the study area and to coincide with previous studies for comparison. For purposes of this report, partial development refers to the period including predevelopment conditions to 1986. Current (2006) conditions were based on water levels measured in 98 wells in the study area during October 23-27, 2006. Maps were constructed of partial development and October 2006 conditions for the unconfined and confined aquifers. These maps were then used to develop the maps showing water-level changes between the two time periods. In addition, streamflow was measured at 13 sites concurrently with the October 2006 water-level measurements to identify gaining and losing stream reaches. Finally, stream discharge and ground-water levels were analyzed for trends.

\section{Partial Development Ground-Water Levels}

Historic ground-water levels used for the partialdevelopment ground-water level maps were obtained from the USGS National Water Information System (NWIS) and the Idaho Department of Water Resources (IDWR) wellinformation and ground-water level databases. Water-level measurements stored in these databases were made at different dates throughout the year and over a range of years. However, there were insufficient ground-water level measurements during October of a single year to represent the entire Wood River Valley aquifer system. Therefore, it was necessary to use water levels from multiple years and months.

The decennial census data shown in figure 3 shows a relatively stable Blaine County population through 1970; ideally, water levels measured prior to 1970 would be used to construct a predevelopment map representing stable ground-water withdrawal and consumption rates. However, there are insufficient pre-1970 water-level measurements to adequately represent the entire Wood River Valley aquifer system. Consequently, water-level data collected as recently as 1986 was selectively used to expand map coverage into recently developed areas. Because these later water-level data were collected after significant development began, the conditions represented are more properly described as partial development. Despite this broad definition of partial development, historic data still were unavailable for some tributary canyons, and thus are not included on the partial development ground-water level maps. In addition, despite the desirability of comparing water levels collected in October of partial-development years to October 2006 levels, groundwater levels measured during August through December were used to construct the partial-development maps because an insufficient number of historic October measurements were available. The final set of historic ground-water level measurements contained historic (1952-1986) water levels for 242 wells: 206 wells in the unconfined aquifer and 36 wells in the confined aquifer (appendix A).

The compromises described here are often necessary in the analysis of past ground-water conditions. They are made assuming that monthly and annual water-level fluctuations were less than $10 \mathrm{ft}$ prior to 1986, an assumption discussed in more detail in sections, "Estimating Water-Level Change" and "Annual and Long-Term Fluctuation of Water Levels." Because streamflow in the area is intimately related to groundwater levels, it integrates upgradient ground-water conditions and is thus another indicator of water-table variation when used in conjunction with the maps. It should also be cautioned that, except where historic and October 2006 water-level measurements coincide, the maps of water-table change indicate broad conditions and may not be suitable for precise site-specific interpretation of change.

The 242 wells used for the partial-development maps were recorded in the NWIS database with elevation accuracies ranging from 0.01 to $20 \mathrm{ft}$, depending on whether the elevation was determined from topographic maps, level surveys from benchmarks, or Global Positioning System surveys. The IDWR well-information database does not contain elevation accuracies for the wells it contains. Elevations for the wells used to construct the partial-development maps were determined from 10-meter digital elevation models (DEMs) for all wells with an elevation accuracy greater than $1 \mathrm{ft}$. There were 26 coincident wells between the 2006 and partialdevelopment ground-water levels. For these wells, the Global Positioning System (GPS) surveyed elevations were used. The 2006 surveying methods and accuracy are discussed in section, "Survey of Well Locations."

The GPS-surveyed elevations, the NWIS-listed well elevations, and well elevations derived from 10-meter DEMs were compared for the 98 wells measured in October 2006 in order to qualitatively evaluate the accuracy of the water-level changes determined by the GIS methods used to generate the change maps (appendix A). Overall, the average difference between the DEM-derived elevation and the GPS-surveyed elevation of the 98 wells was smaller than the average difference between the NWIS-listed well elevation and GPS-surveyed elevation. The mean, median, and range for the GPS/DEM elevation comparison were 5.1, 2.8, and $26.8 \mathrm{ft}$, respectively. For the GPS/NWIS elevation comparison, the mean, median, and range were 15.3, 3.1, and 1,000 ft, respectively. The NWIS elevations had one obvious outlier. However, if the outlier is removed, then the mean, median, and range for the GPS/NWIS comparison for the remaining 97 wells are still greater than that of the GPS/DEM comparison. 
Of the 98 GPS-surveyed wells, 18 were listed in NWIS with elevation accuracies of $1 \mathrm{ft}$ or less. The comparisons of just these higher accuracy elevations in NWIS with the DEM and GPS derived elevations resulted in the DEM comparison having a mean, median, and range of 1.7,1.2, and $7.4 \mathrm{ft}$, respectively, which are larger than the NWIS comparison.

\section{October 2006 Ground-Water-Level Measurement}

Water levels in 98 wells in the Wood River Valley study area were measured by personnel from the USGS during October 23-27, 2006. In non-flowing wells, ground-water levels were measured using either steel tapes or calibrated electric tapes. In flowing wells, water levels were measured with a calibrated digital pressure gage. Of the 98 wells, 10 wells were completed in the confined aquifer, and the remaining wells were completed in the unconfined aquifer.

Well locations were selected to represent groundwater levels throughout the Wood River Valley, but parts of the study area lacking wells are inadequately represented. Although an emphasis was made to find wells located in the tributary canyons in the northern part of the study area and the transitions of the canyons with the main Wood River Valley, these canyons often contained few available wells.

\section{Survey of Well Locations}

Elevations of the 98 wells were measured using a combination of real-time kinematic (RTK) and fast-static differential GPS-surveying techniques. Trimble 5700 and 5800 GPS systems were used for the surveying. In areas with poor satellite reception, a nearby location with good reception was selected, and a Topcon GTS-312 electronic total station was used to survey the well location relative to the GPS-surveyed location. GPS surveying data were processed with Trimble Geomatics Office software (Trimble Navigation Ltd., 2007), and any well that was surveyed using the total station was corrected to its proper GPS position.

Errors in the GPS fast-static surveying ranged from 0.02 to $0.26 \mathrm{ft}$ horizontally and 0.05 to $0.52 \mathrm{ft}$ vertically, with a mean horizontal error of $0.07 \mathrm{ft}$ and a mean vertical error of $0.16 \mathrm{ft}$. The RTK survey method produced smaller positional precision errors. However, because each surveyed point originated from a fast-static surveyed position, these errors translated into the larger fast-static original position errors. Fast-static errors are a result of short measurement times, poor satellite reception due to areal obstructions (such as tree cover or narrow canyons), or lack of satellites available at the time of measurement. The fast-static technique was used in areas where RTK was not possible.

\section{Ground-Water-Level Maps}

The October 2006 and partial-development ground-water level maps were produced using a geographic information system (GIS). The study area boundary was defined by using a DEM converted to a slope model to determine the transition from the adjacent bedrock hills (high slope values) to the flat portions of the valley filled with unconsolidated sediment (low slope values). This transition represents the approximate location of the boundary between the unconfined aquifer and the adjacent bedrock in the tributary canyons and the main valley. This location matches the approximate aquifer boundary defined by Moreland (1977) and Frenzel (1989), and the Quaternary alluvium boundary defined in Worl and Johnson (1995) and in Breckenridge and Othberg (2006).

The ground-water-level surfaces were created using a spline interpolator technique that includes barriers in order to incorporate the effects of aquifer boundaries along the narrow northern valley and tributary canyons (Environmental Systems Research Institute, Inc., 2007). The spline interpolator is a deterministic interpolator that creates a smooth surface that must pass through each measured value. It is ideal for smoothly varying surfaces such as a typical potentiometric surface. The output of the spline interpolator is a grid with an interpolated value at each cell except for those cells containing a ground-water-level measurement that is assigned the measured ground-water level. The cell size for the resultant grids is $10 \times 10 \mathrm{~m}$.

The spline interpolator was applied to the entire study area except in the vicinities of Warm Springs Creek on the October 2006 map and Trail Creek on the partial-development map. The spline with barriers interpolator did not provide hydrologically realistic results due to a lack of data in these two areas, so a tension spline interpolator was used instead. The resulting grids for each map were then combined to create one ground-water surface map. Contour lines were then created from the ground-water surface map for display purposes (pls. 1 and 2).

The tension spline technique includes a weight option that controls the amount of curvature in the interpolated surface between known ground-water level points and an option to determine the number of data points used in the calculation of each interpolated cell. The two areas in which the tension spline technique was utilized used high weights (value of 10), allowing for more variation in the output surface at a greater distance from the data points. The few data points available in these areas resulted in less control of the interpolated surface for the tributary canyons. 
The confined aquifer was evaluated separately for the October 2006 and partial-development potentiometricsurface maps with ground-water level measurement data from wells completed in the confined aquifer. The tension spline interpolator was used to create these maps because the data is contiguous and no irregular barriers or boundaries isolate data points. The confined aquifer interpolations also used as many available data points as possible for the October 2006 potentiometric-surface map (due to the limited amount of data available) and used a weight option of 10 . The partialdevelopment potentiometric surface map was created using this same interpolator and settings.

Cells of the interpolated surfaces or grids are better controlled when the interpolated cell is surrounded by data points. The interpolator will evaluate cells if there are data points on only one side of the evaluated cell. This can have unpredictable results due to the lack of control over the interpolated cell. All sections of contour lines derived from interpolated cells that are surrounded by actual data points are displayed as a solid line, whereas the remaining contours are dashed to indicate this lack of control over the interpolated value of the grid cell. The potentiometric surfaces derived from wells completed in the confined aquifer are only defined for the areas between or surrounded by ground-water level data points because the full extent of the confined aquifer is not well known.

\section{Estimating Water-Level Change}

Water-level changes between partial-development and October 2006 ground-water maps were estimated by using a GIS to subtract the October 2006 water-level surfaces of the unconfined and confined aquifers from the partialdevelopment water-level surfaces. The results are groundwater level change maps for the two aquifers showing changes in the water-table and potentiometric surfaces. Lines representing water-level change were then created from the resulting ground-water change surfaces-ground-water level declines are shown as negative values and ground-water-level rises are shown as positive values.

For the water-level change maps, any line that was within both the October 2006 and partial-development maps' solidline contour was displayed as a solid line. If the line occurs in an area where either the October 2006 or partial-development maps' lines were dashed, then the water-level change map was dashed to indicate an interpolated value with less confidence.

As previously described in section, "Partial Development Ground-Water Levels," historic data were not always available to match the exact timing of the October 2006 groundwater level measurement. Therefore, it was necessary to use measurements made August through December from 1952 through 1986 to augment the dataset. To evaluate the effect of natural annual and multi-year variation in ground-water levels on the water-level change maps, wells with multiple water-level measurements were analyzed to constrain probable variation. The maximum water-level range was calculated for a well with multiple water-level measurements for a single year during the 5-month period from August to December as well as the entire year. A well could have several water-level range calculations if it was measured multiple times during multiple years. The range of water-level measurements in wells vary from those measured only twice during the period of record to those measured multiple times in a single week.

\section{Surface-Water Discharge Measurements}

Streamflow was measured at selected sites in order to evaluate the interaction between ground and surface water. Changes in streamflow between measurement points on a stream indicate whether the stream is gaining flow from ground-water discharge (an increase in flow between the stations) or if the stream is losing flow to ground-water and recharging the aquifer (a decrease in flow between the stations). Late October was selected for the mass-measurement of ground-water levels and streamflow because the irrigation season and related surface-water diversion typically ends by mid-October, and July-October usually are the driest months of the year. Consequently, streamflow from small tributary basins and the return flow from drains have ceased by late October.

During October 23-27, 2006, streamflow was measured at 13 sites: 7 on the Big Wood River, 3 on its tributaries, 1 on a diversion, and 2 on Silver Creek (fig. 4). However, during the week of October 23-27, 2006, a large number of tributary streams were still flowing into the Big Wood River, and many active diversions were still removing water for irrigation. Because of the large number of streams and diversions, not all inflows and outflows to the Big Wood River could be measured for discharge. Without measuring the discharge of each individual inflow and outflow, the comparison of flow between each measurement site is somewhat limited and accurate calculation of stream gains and losses is not possible for the entire river reach.

Measurements of discharge were made with a current meter using the general methods adopted by the USGS. These methods are described in USGS Water-Supply Paper 2175 (Rantz, 1982; Rantz and others, 1982) and the Techniques of Water-Resources Investigations of the United States Geological Survey (TWRIs), Book 3, Chapters A1 through A19 and Book 8, Chapters A2 and B2, which may be accessed at http://water.usgs.gov/pubs/twri/. 


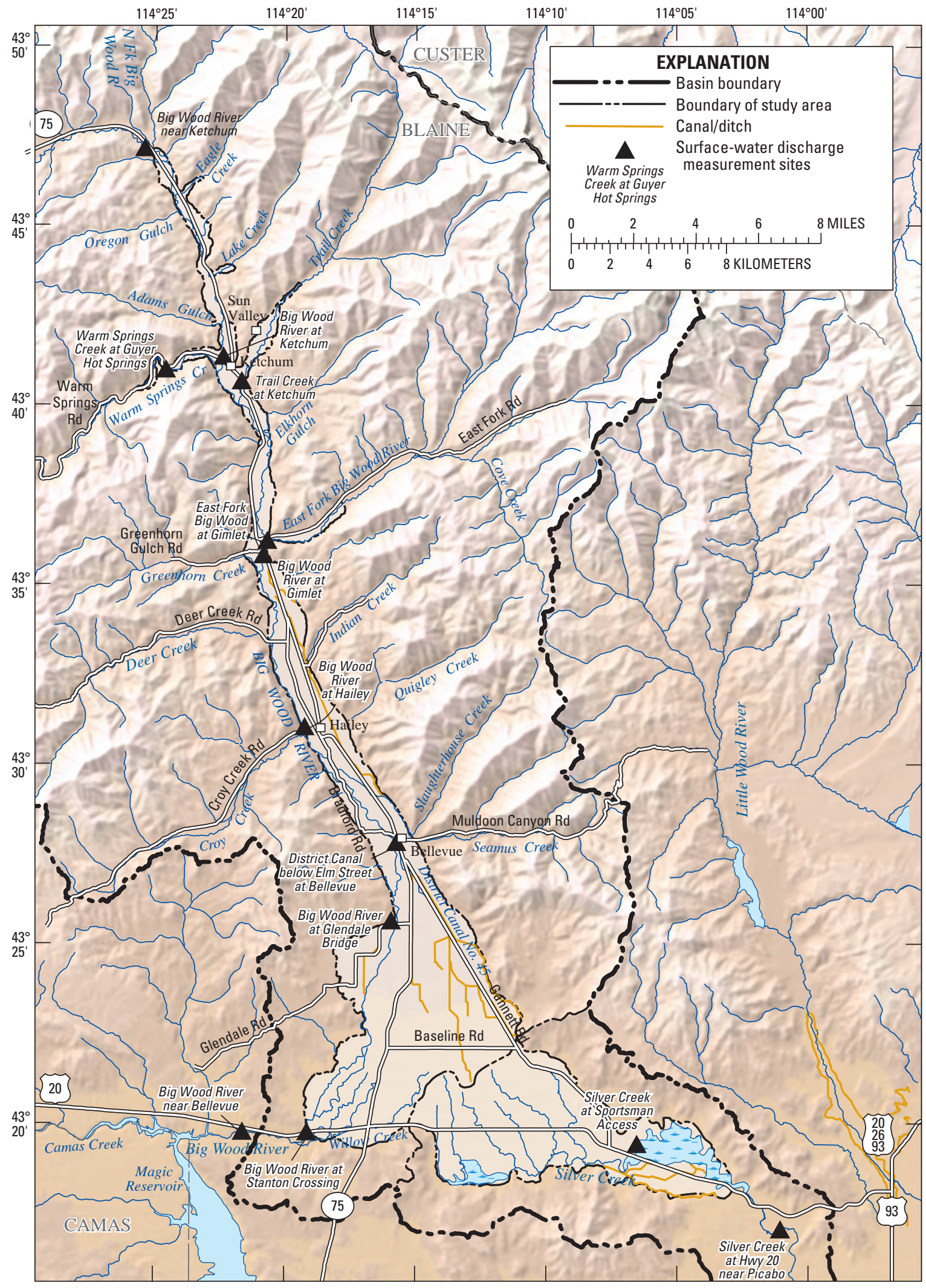

Figure 4. Location of surface-water discharge measurements, Wood River Valley, central Idaho, October 23-26, 2006. 


\section{Trend Analysis}

\section{Ground-Water Level Trends}

Temporal trends in ground-water levels for three wells in the Wood River Valley with more than 50 years of measurements varying in frequency from weekly to biannually were evaluated using techniques described in section, "Ground-Water Level Trend Analysis." All three wells, 432042114163801, 432143114114301, and 432657114144801, showed statistically significant (the level of significance, or p-value, was less than 0.005) declining trends in ground-water levels. Well 432042114163801 is completed in the confined aquifer near the intersection of U.S. Highway 20 and State Highway 75. The remaining two wells are completed in the upper unconfined aquifer: well 432143114114301 near Gannett and well 432657114144801 south of Bellevue.

To examine the response of water levels to precipitation, normalized plots of mean annual depth to water for the three wells and total annual precipitation at the Ketchum Ranger Station were constructed as described in section, "GroundWater Level Trend Analysis" (fig. 5). Although there is broad agreement of trends and many individual years between the water level and precipitation plots, a large number of years do not match or show water-level declines in response to periods of increased precipitation. A simple linear regression between water levels and precipitation confirms a poor correlation between the two: all $\mathrm{R}^{2}$ (coefficient of determination) values are less than 0.5. This lack of correlation is further confirmed in that water levels in these three wells show statistically significant downward trends, while, as previously mentioned, total annual precipitation at the Ketchum Ranger Station shows a statistically weak ( $p$-value of 0.258 ) increasing trend.

Water levels in the three wells unquestionably respond to recharge from precipitation. However, other factors such as withdrawals, infiltration from surface-water irrigation (including canal leakage), and land-use changes probably have an effect. Water levels in these wells also have fluctuated over their period of record. Table 6 shows the extremes and annual variation of ground-water levels in these three wells.

The statistically significant downward trend in groundwater levels helps to explain the statistically significant downward trends in low-flow values for the Big Wood River near Bellevue and the Silver Creek at Sportsman Access gaging stations. Because both streams are fed largely by ground water in these reaches, any lowering of ground-water levels will reduce streamflow.

\section{Streamflow Trends}

During analysis of streamflow at the Big Wood River at Hailey gaging station, it was observed that flows prior to 1945 had periodically decreased to zero due to upstream diversions at the Justus Ditch for hydroelectric production and seasonal irrigation. An unknown quantity of water was then returned to the river downstream of the gaging station. Use of the ditch was discontinued sometime in the late 1970 s to early 1980 s. The combined records of the Big Wood Slough at Hailey and the Big Wood River at Hailey were used during this period for trend calculations.

No statistically significant trends were found in the mean annual streamflow for the Big Wood River at Hailey gaging stations (table 5). A statistically significant trend exists for the mean monthly flow for March, for which there was a 25-percent increase in mean monthly base flow from 1951-2005 (p-value of 0.005). A weak statistical increasing trend also exists for January ( $p$-value of 0.123). The March increase in streamflow may be a function of earlier snowpack runoff, seen in basins throughout the Western United States (Stewart and others, 2005).

Analysis of the annual 7- and 30-day low-flow calculations at the Big Wood River at Hailey gaging stations indicate an increase in base flow (water years 1915-2005). Weak statistical trends for the 7-day (p-value of 0.117) and 30-day ( $p$-value of 0.097) low-flow calculations suggest an increase of $20 \mathrm{ft}^{3} / \mathrm{s}$ since 1915 (fig. 6A). As mentioned in the section, "Streamflow Trend Analysis," the confidence interval for surface-water analysis in this report was restricted to 90 percent; while the trends for 7-day and 30-day low-flow calculations have confidence intervals of 88 and 90 percent, respectively, they may suggest a developing trend. If these trends exist, a possible explanation may be a statistically weak increasing trend ( $p$-value of 0.258 ) of total annual precipitation at the Ketchum Ranger Station.

The Big Wood River near Bellevue gaging station (13141000) did not have a statistically significant annual trend in discharge or a BFI trend (table 6). However, mean monthly discharge values show statistically significant decreasing trends for December, January, and February ( $p$-values of $0.014,0.006$, and 0.095 , respectively, fig. 7). Statistically significant decreasing trends also exist for both the 7-day and 30-day low-flow analyses (p-values of 0.084 and 0.076 , respectively), showing a mean decrease of about $15 \mathrm{ft}^{3} / \mathrm{s}$ since the 1940 s (fig. 6B).

To examine whether or not ground-water inflow has changed, data from the Silver Creek at Sportsman Access near Picabo gaging station (13150430) was examined for trends. 


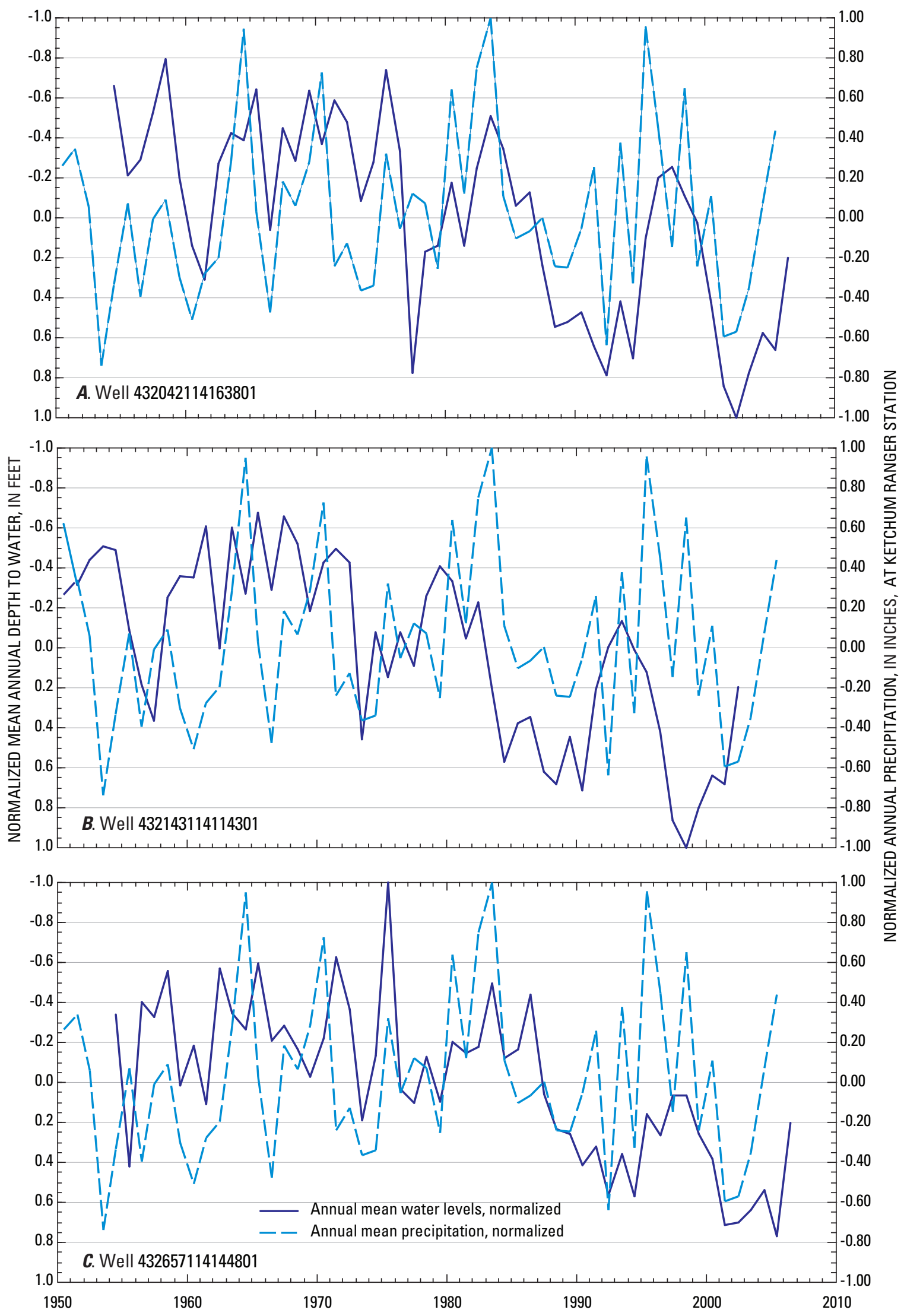

Figure 5. Normalized residual plots of mean annual depth to water for three wells and total annual precipitation at the Ketchum Ranger Station, Wood River Valley, south-central Idaho. 


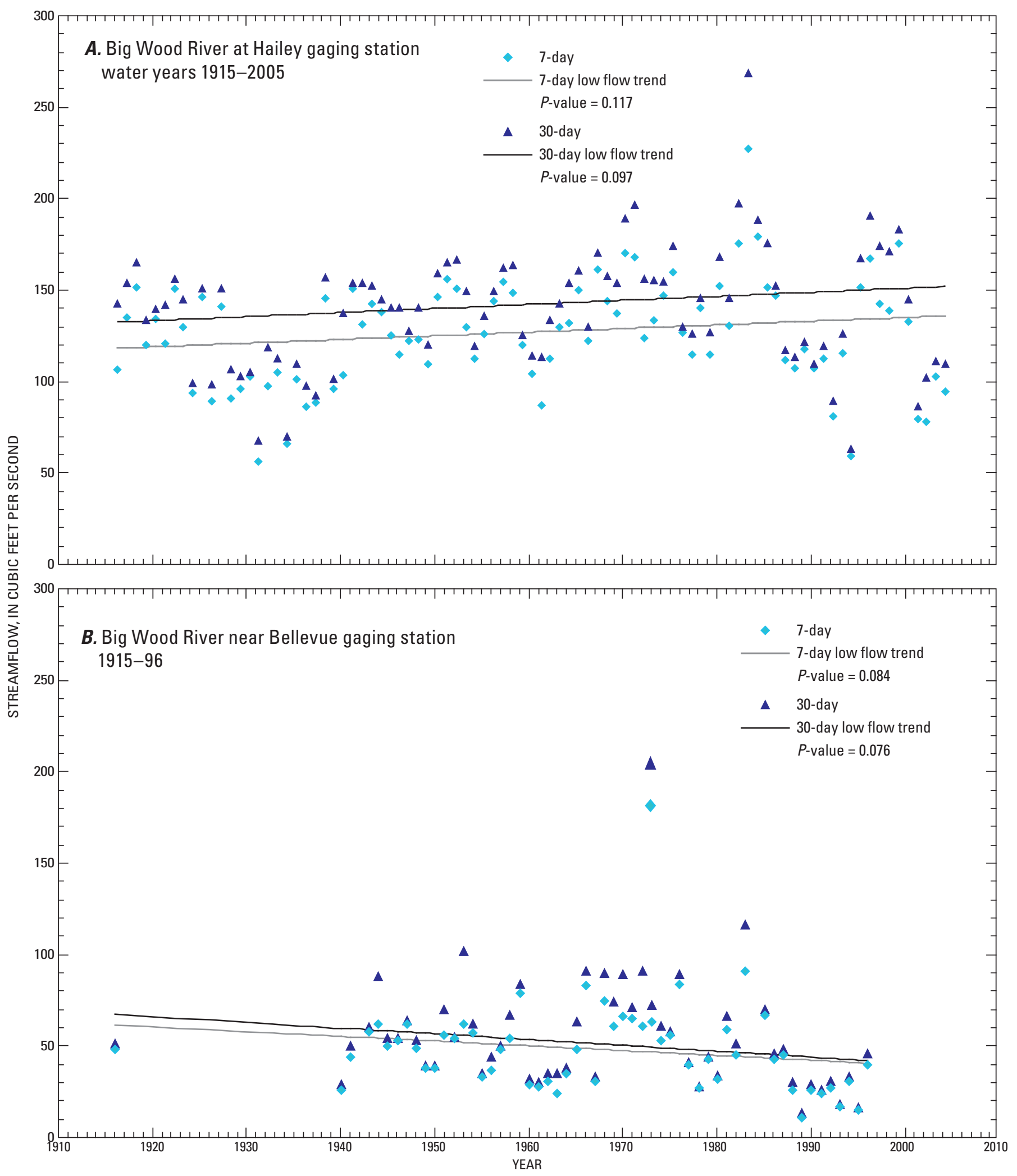

Figure 6. Trend analysis of annual 7- and 30-day low streamflows for two gaging stations on the Big Wood River, southcentral Idaho. 
Table 6. Extremes of ground-water levels and annual variation for selected wells in the Wood River Valley, south-central Idaho, 1954-2006.

[Annual variation is calculated for calendar year. Water levels are depth below land surface, negative numbers indicate height above land surface. Abbreviations: USGS, U.S. Geological Survey; ft, foot]

\begin{tabular}{|c|c|c|c|c|c|c|c|c|c|c|c|}
\hline \multirow[b]{2}{*}{ USGS well No. } & \multirow[b]{2}{*}{ Well name } & \multicolumn{4}{|c|}{ Water levels (ft) } & \multirow{2}{*}{$\begin{array}{c}\text { Mean } \\
\text { depth to } \\
\text { water, } \\
\text { period of } \\
\text { record (ft) }\end{array}$} & \multicolumn{5}{|c|}{ Annual variation in water levels (ft) } \\
\hline & & Lowest & Date & Highest & Date & & Maximum & Year & Minimum & Year & $\begin{array}{c}\text { Mean, period } \\
\text { of record }\end{array}$ \\
\hline 432042114163801 & 01S 18E 14AAB1 & -11.33 & $06-27-58$ & -46.47 & $09-22-94$ & -27.25 & 20.04 & 1958 & 1.54 & 2005 & 8.82 \\
\hline 432143114114301 & 01S 19E 03CCB2 & 26.05 & $11-03-94$ & 2.55 & $08-12-65$ & 14.95 & 15.46 & 1962 & 1.53 & 1996 & 9.41 \\
\hline
\end{tabular}

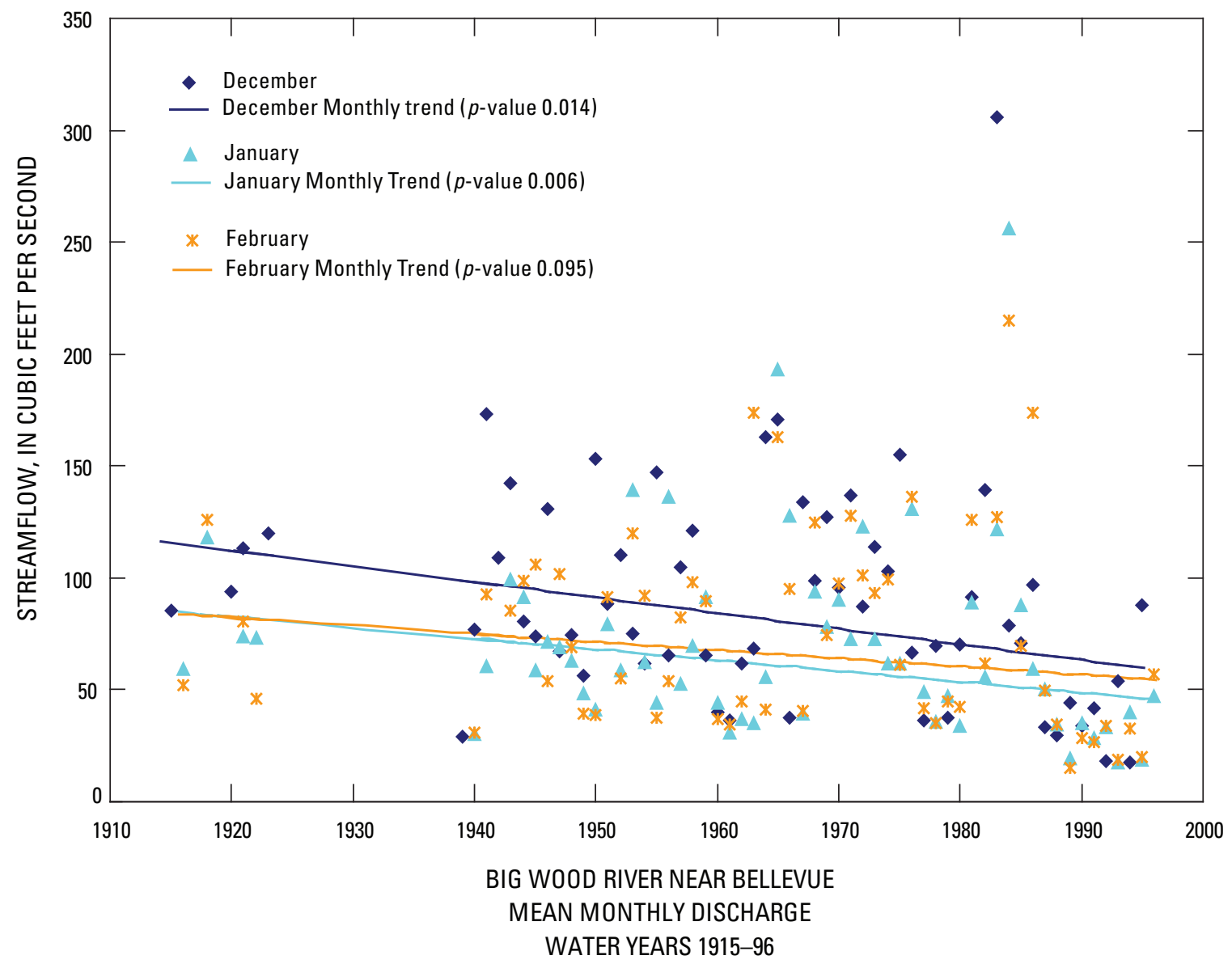

Figure 7. Mean monthly discharge at Big Wood River near Bellevue, south-central Idaho, water years 1915-96. 
Because Silver Creek and its tributaries are fed primarily by ground water discharging through seeps and springs, and because irrigation diversions and returns to and from Silver Creek are minimal, seasonal fluctuations in streamflow are directly related to water levels in the Wood River Valley aquifer system (Moreland, 1977). Therefore, streamflow in Silver Creek can be used as a proxy for trends in ground-water discharge to the Big Wood River on the Bellevue fan. Silver Creek at Sportsman Access has a statistically significant annual discharge decreasing trend ( $p$-value of 0.018) for the period of 1975-2005 and mean monthly discharge values at this gaging station also show statistically significant decreasing trends for July through February and April (p-values all less than 0.052), table 5. Statistically significant decreasing trends also exist for both the 7-day and 30-day low-flow analyses ( $p$-values of 0.074 and 0.101 , respectively). The Silver Creek at Sportsman Access gage data did not have a statistically significant trend for the BFI analysis.

The decreasing trends in the Big Wood River near Bellevue since the 1940s, and in Silver Creek since 1975, indicate declining ground-water levels. There have been wet and dry cycles during this time. However, population has increased since the 1960s, and therefore the declines in ground-water levels could be due to increased consumptive use of water in the valley from increased population. Increased consumptive use may result in lowered ground-water levels, which reduces spring flows to the Big Wood River and Silver Creek. These reduced flows are most evident during the winter months for the Big Wood River near Bellevue gage since flow is primarily derived from ground-water inputs to the river during this time. Because Silver Creek is spring fed year round the effect of declining ground-water levels is evident for most of the year. More information is needed on water-use patterns to test this hypothesis.

\section{Partial Development and October 2006 Hydrologic Conditions}

\section{Unconfined Aquifer}

\section{Partial-Development Water Table}

The map of the partial-development water table in the unconfined aquifer is shown on plate 1 . Although waterlevel measurements from 206 wells were used to construct this map (see section, "Ground-Water-Level Maps"), waterlevel measurements were not available for some areas of the unconfined Wood River Valley aquifer system for the partial-development period. This is true for three of the eight tributary canyons shown on the October 2006 water-table map (Croy Creek, Indian Creek, and Deer Creek). Thus, partialdevelopment conditions are not shown for these areas. Watertable contours for the northern part of the study area and all mapped tributary canyons were approximated due to a lack of data in those areas.

The partial-development map generally shows a uniform southerly water-table gradient until the Bellevue fan, at which point the gradient decreases and a poorly defined groundwater divide forms and gradients slope to either the southwest toward the discharge area of the Big Wood River and Willow Creek or southeast toward the discharge area of Silver Creek.

\section{October 2006 Water Table}

The October 2006 water-table map of the unconfined aquifer in the Wood River Valley was constructed from 88 wells and is shown on plate 2. The map includes the main valley and eight tributary canyons and shows a uniform gradient southward until the Bellevue fan where the valley widens and the ground-water gradient declines. A groundwater divide forms near Baseline Road; it trends nearly due south, thus splitting the gradient to the southwest and southeast.

Previous studies show a seasonal migration of the ground-water divide with a westward shift during the irrigation season (May to October) and a return eastward during autumn and winter. This is due to increased recharge to ground water in the middle to eastern part of the Bellevue fan and decreased infiltration from the Big Wood River along the western edge of the Bellevue fan as a result of decreased or no streamflow during this period (Castelin and Chapman, 1972). Castelin and Chapman's (1972) map of May ground-water conditions shows an eastward position of the divide. Smith's (1959) map shows ground-water conditions during August and a central position of the divide. Moreland's (1977) map, along with this study, shows October ground-water conditions and a westward position of the divide. Although the west-east shift apparently occurs annually, its actual position may vary from year to year due to changes in irrigation, pumping, land use, and precipitation. The ground-water divide is not as well-defined on the partial-development water-table map as it is for the October 2006 water-table map. This is most likely due to the range of dates used in the creation of the partial-development map: 5 months over a 35-year period as opposed to a single week in October 2006. 


\section{Changes in the Water Table, Partial Development to October 2006}

The water-table change map of the unconfined aquifer (pl. 3) shows changes in the water table at a 10-ft interval; negative values indicate a decline in ground-water level between the partial-development and October 2006 watertable maps, and positive values indicate a rise in ground-water levels. Dashed lines indicate uncertainty in either the partialdevelopment or October 2006 water-table maps. Some of the \pm 10 -ft lines are dashed to represent water-level changes in this range falling within the average range of water-level fluctuation $(5 \mathrm{ft})$ plus the average elevation uncertainty of the partial-development map (5 ft). These dashed lines occur in areas influenced by partial-development wells with elevation accuracies greater than $1 \mathrm{ft}$.

Changes in the water table in the study area north of Ketchum primarily indicate no change or an increase in ground-water levels. However, ground-water level changes in this area are approximated due to the lack of data coverage. Ground-water level declines are small in the upper and lower parts of the Warm Springs tributary canyon, with a large rise in ground-water levels in the middle section. Ground-water levels rose in the upper part of the Trail Creek tributary and declined in the lower part of the tributary. Ground-water levels in this tributary canyon, as well as all others, were approximated due to the lack of data coverage. Ground-water levels primarily declined or did not change in the area from Ketchum south to Indian Creek, with ground-water level rises in three areas. Ground-water levels declined or did not change in the remainder of the study area south of the Indian Creek tributary. Ground-water levels declined more than $10 \mathrm{ft}$ in the area southwest of Bellevue near Glendale Road. Moreland (1977) found this area to have natural ground-water level fluctuations as much as $40 \mathrm{ft}$, but water-level fluctuation calculations performed for this study show fluctuations of less than $40 \mathrm{ft}$. Ground-water levels declined greater than $10 \mathrm{ft}$ in the southeastern part of the study area near Picabo; Moreland (1977) noted that ground-water levels in this area fluctuate less than in other parts of the study area.

\section{Confined Aquifer}

\section{Partial-Development Potentiometric Surface}

The partial-development potentiometric-surface map of the confined aquifer was constructed using ground-water levels measured in 36 wells. The partial-development map (pl. 4A) shows a broad area of high water levels (fairly well defined because of the number of measurements used), from which gradients slope to the southwest and east.

\section{October 2006 Potentiometric Surface}

The October 2006 potentiometric-surface map of the confined aquifer was constructed using ground-water levels measured in 10 wells, and is shown on plate 4B with $10-\mathrm{ft}$ contours. Even with the limited number of data points, the October 2006 potentiometric-surface map shows a broad area of high water levels from which gradients slope to the southwest and east.

\section{Changes in the Potentiometric Surface, Partial Development to October 2006}

The potentiometric-surface change map (pl. 4C) predominately shows declines in ground-water levels greater than $10 \mathrm{ft}$. Moreland (1977) found natural water-level fluctuations of $10 \mathrm{ft}$ or less in these areas, although Castelin and Chapman (1972) indicated ground-water level fluctuations of $5 \mathrm{ft}$ or less in these same areas.

\section{Annual and Long-Term Fluctuation of Water Levels}

Previous authors have noted large annual fluctuations of water levels in the Wood River Valley aquifer system. Therefore, annual and August-December fluctuations were evaluated for different years in 376 wells completed in the unconfined aquifer and 121 wells completed in the confined aquifer. In the unconfined aquifer, the mean water-level range for the August to December period is approximately $5 \mathrm{ft}$ with a maximum of $70 \mathrm{ft}$. In the confined aquifer, the mean water-level range for the August to December period is approximately $3 \mathrm{ft}$ with a maximum of $20 \mathrm{ft}$. Castelin and Chapman (1972) documented larger water-level fluctuations; however, their analysis used water levels measured during May to August and May to October. Moreland (1977) found annual ground-water level fluctuations ranging from 5 to $40 \mathrm{ft}$ depending on the well location in the study area. The smallest fluctuations were in the southeastern part of the study area because of spring discharge into Silver Creek and its tributaries. Ground-water level fluctuations are somewhat damped by seeps and springs because increases in groundwater levels increase seep and spring discharge thus tempering the ground-water level rise. As ground-water levels decline, seep and spring discharge decreases. The largest fluctuation rates were near the intermittent reach of the Big Wood River below Glendale Road because of surface-water diversions. Because wells used in this analysis have varying measurement dates and measurement frequencies, no coherent spatial distribution similar to that found by Castelin and Chapman (1972) is apparent. 


\section{Surface-Water Discharge Measurements and Streamflow Gain/Loss}

During October 23-27, 2006, stream discharge was measured at 13 sites: 7 on the Big Wood River, 3 on its tributaries, 1 on a diversion, and 2 on Silver Creek (fig. 4). Measured discharge at each site and change in discharge between sites is shown in table 7, listed in downstream order. The three measured tributaries of the Big Wood River enter the river between the former sites of the Big Wood River at Ketchum (13136000) and the Big Wood River at Gimlet (13138500) gaging stations.

Changes in the discharge of the Big Wood River in the Wood River Valley primarily was due to flow from tributaries in the northern part, ground-water outflow, inflow and surface-water diversions in the southern part, and a mixture of these factors in the central part. As measured in October 2006, discharge in the Big Wood River increased by $46 \mathrm{ft}^{3} / \mathrm{s}$ from the Big Wood River near Ketchum (13135500) site to the Big Wood River at Ketchum (13136000) site, which was attributed to the inflow of small streams such as the North Fork Big Wood River, Eagle Creek, and Lake Creek. Measurement error at these sites could account for up to $5 \mathrm{ft}^{3} / \mathrm{s}$ of the measured flow. Discharge increased by $101 \mathrm{ft}^{3} / \mathrm{s}$ between the Big Wood River at Ketchum (13136000) site and the Big Wood River at Gimlet (13138500) site; most of this gain was from the combined $82 \mathrm{ft}^{3} / \mathrm{s}$ inflow measured at the Warm Springs Creek at Guyer Hot Springs (13136500), Trail Creek at Ketchum (13137500), and the East Fork Big Wood River near Gimlet (13138000) sites. The remaining $19 \mathrm{ft}^{3} / \mathrm{s}$ was attributed to ungaged inflow from Elkhorn Gulch, inflow from the wastewater-treatment facility, ground-water seepage into the river, and measurement error. Measurement error could account for most of this inflow to the Big Wood River. Discharge in the Big Wood River increased about $32 \mathrm{ft}^{3} / \mathrm{s}$ from the Big Wood River at Gimlet (13138500) to the Big Wood River at Hailey (13139500) sites. Of the ungaged tributary basins in this reach, Greenhorn Creek and Deer Creek are the most likely to contribute significant flow to the river. The wastewater-treatment facilities input a minimal amount of flow in this reach (less than $2 \mathrm{ft}^{3} / \mathrm{s}$ ) (M.A. Maupin, written commun., 2007) and measurement error could account for up to half of the additional flow. Due to diversions and seepage to ground water, the channel of the Big Wood River is typically dry for most of the reach between the District Canal below Elm Street, at Bellevue diversion (13140350) and the Big Wood River at Glendale Bridge (13140500) sites except during snowmelt and intense precipitation events. During October, 2006, the entire flow of the Big Wood River

Table 7. Streamflow measurements, Wood River Valley, south-central Idaho, October 23-26, 2006.

[Abbreviations: $\mathrm{ft}^{3} / \mathrm{s}$, cubic foot per second; $\mathrm{mi}^{2}$, square miles; - , no flow or not applicable]

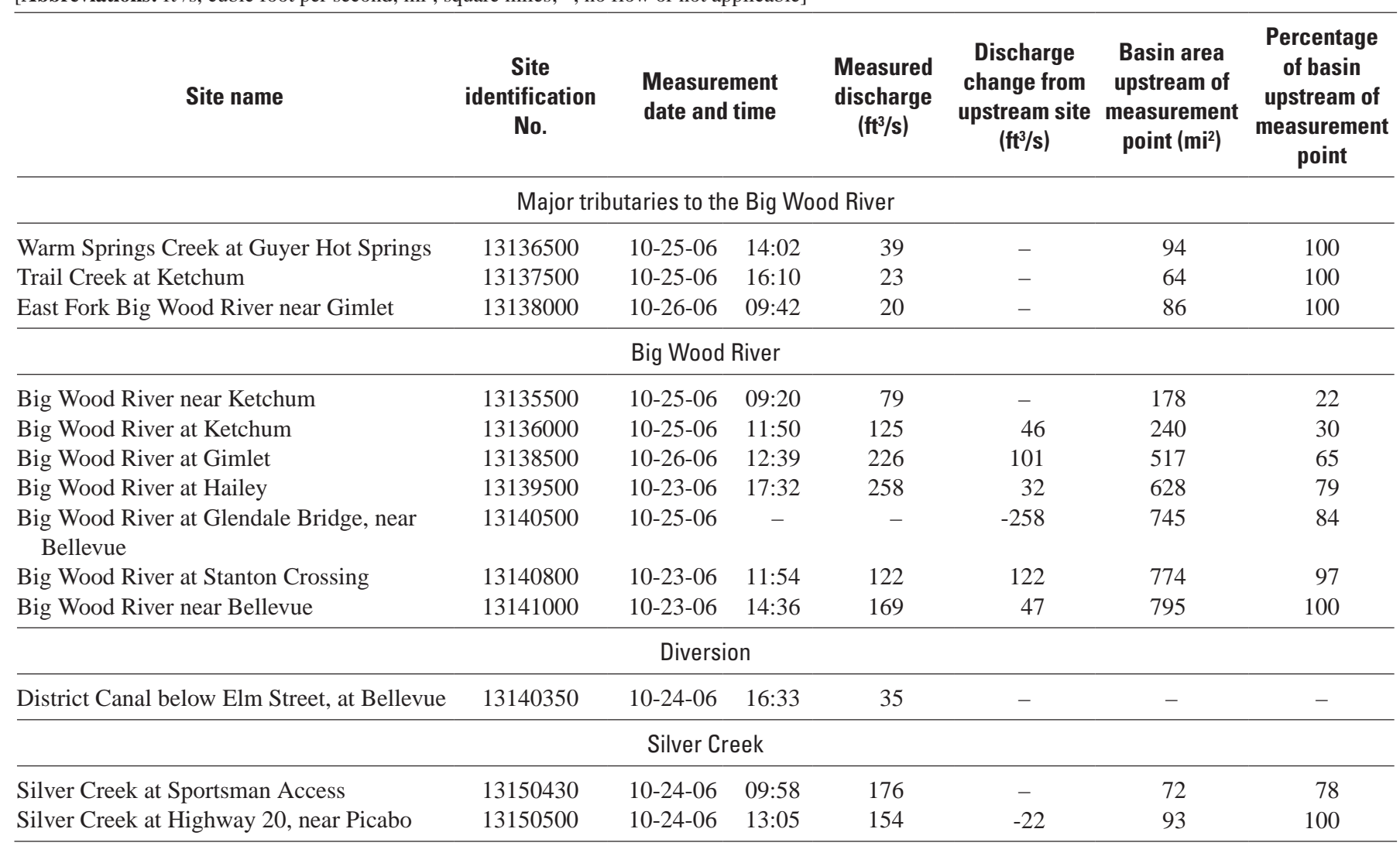


was still diverted into the District Canal below Elm Street, at Bellevue diversion (13140350), which had a discharge of $35 \mathrm{ft}^{3} / \mathrm{s}$. The river remained dry for many miles until groundwater seepage into the river reaches $122 \mathrm{ft}^{3} / \mathrm{s}$ at the Big Wood River at Stanton Crossing (13140800). The river gained an additional $47 \mathrm{ft}^{3} / \mathrm{s}$ before it reached the Big Wood River near Bellevue (13141000) site, a quarter of which could be due to measurement error.

Surface-water discharge measurements and streamflow gain/loss analyses on the Big Wood River have been made by Castelin and Chapman (1972) for February 1971; Moreland (1977) for the week of September 29-October 1, 1975; Luttrell and Brockway (1984) for September 12-14, 1983, and March 12-14, 1984; and Frenzel (1989) for August 1986. Because measurement sites and times, and more importantly, discharge varied among the studies, direct comparison among them is difficult. However, allowing for different measurement points, the general identification of gaining and losing stream reaches on the Big Wood River and Silver Creek for this study generally agree with previous studies.

Two discharge measurements were made on Silver Creek on October 24, 2006, for this study. Discharge was 176 $\mathrm{ft}^{3} / \mathrm{s}$ at the Silver Creek at Sportsman Access gaging station (13150430) and $154 \mathrm{ft}^{3} / \mathrm{s}$ at the Silver Creek at Highway 20 near Picabo gaging station (13150500), thus showing a loss of $22 \mathrm{ft}^{3} / \mathrm{s}$ between the gaging stations. Moreland (1977) measured discharge and analyzed streamflow gain/loss on Silver Creek and its tributaries for three time periods in 1975: the weeks of May 19-22, June 23-27, and September 29-October 3. These measurements indicated a loss of 4, 10, and $15 \mathrm{ft}^{3} / \mathrm{s}$, respectively.

\section{Summary and Conclusions}

The Wood River Valley of south-central Idaho extends from Galena Summit southward to the Timmerman Hills. The study area of this report is within the Wood River Valley extending from the boundary with the Sawtooth National Forest southward to the Timmerman Hills. Because the entire population of the area (about 15,000 in 2000) depends on ground-water for domestic supply, either from domestic or municipal-supply wells, rapid population growth since the 1970s has raised concerns about the continued availability of ground and surface water to support existing uses and streamflow.

The Wood River Valley aquifer system includes the Quaternary sediments of the Wood River Valley and its tributaries; and locally, underlying igneous, sedimentary, or metamorphic rocks where they are hydraulically connected and used for water supply. The aquifer system is comprised of a single unconfined aquifer and an underlying confined aquifer present south of Baseline Road. Streams are well-connected to the unconfined aquifer throughout the valley. Depth to water in the upper valley is commonly less than 10 feet, increasing to about 90 feet southward. Water levels in the lower valley range from less than 10 to about 150 feet below land surface in the unconfined aquifer, whereas most wells in the confined aquifer are under artesian pressure and flow.

Most of the Wood River Valley is drained by the Big Wood River or its tributaries, except for the southeastern part of the Bellevue fan, which is drained by the ground-water-fed Silver Creek. The Big Wood River gains flow from a number of perennial and ephemeral tributaries and meanders across the narrow upper valley until Bellevue, where it flows along the western side of the Bellevue fan, finally exiting the valley at Stanton Crossing. A network of irrigation canals and drains exists throughout the study area.

Mean annual water levels in three wells (two completed in the unconfined aquifer and one in the confined aquifer, all in the southern part of the study area) with more than 50 years of semi-annual measurements were evaluated for statistically significant trends. All three show statistically significant declining trends.

Long-term trend analysis was performed on three gaging stations in the Wood River Valley that had at least 20 years of record. The Big Wood River at Hailey gaging station (13139500) showed a statistically significant trend of a 25-percent increase in mean monthly base flow for March over the 90 -year period of record. This increase in streamflow may be a function of earlier snowpack runoff, as seen in basins throughout the Western United States. No statistically significant long-term trends were found in mean annual or calculated BFI values. Both the 7-day and 30-day low-flow analyses for the Big Wood River near Bellevue gaging station (13141000) show a mean decrease of about 15 cubic feet per second since the 1940s, and mean monthly discharge values show statistically significant decreasing trends for December, January, and February. To examine whether or not groundwater inflow has decreased, streamflow in Silver Creek was used as a proxy for trends in ground-water discharge to the Big Wood River on the Bellevue fan. The Silver Creek at Sportsman Access near Picabo gaging station (13150430) showed statistically significant decreasing trends in annual and mean monthly discharge for July through February and April. The 7-day low flow analysis also had a statistically significant decreasing trend.

The decreasing trends at the Big Wood River near Bellevue and Silver Creek gages indicating declining groundwater levels could be due to increased consumptive use of water in the valley from increased population. Increased consumptive use may result in lowered ground-water levels which reduces spring flows to the Big Wood River and Silver Creek. These reduced flows would be most evident during the winter months for the Big Wood River near Bellevue gage since flow are primarily derived from ground-water inputs to the river during this time. Since Silver Creek is spring fed year round the effect of declining ground-water levels is evident for most of the year. 
Using a GIS, current and partial-development groundwater level maps were made of the unconfined and confined aquifers, along with ground-water level change maps between the two development periods. Development conditions in the valley were based on decennial census data that shows a relatively stable Blaine County population through 1970 , after which it increased from 5,749 in 1970 to 21,166 in 2005. Ideally, ground-water levels measured prior to 1970 would be used for a pre-development map, but pre-1970 water-level measurements are insufficient to construct a map of the entire valley. Therefore, ground-water levels measured up to 1986 were used to represent the partial-development period.

In general, the current and partial-development watertable maps of the unconfined aquifer show a uniform southerly gradient until the Bellevue fan, at which point the gradient decreases and a poorly defined ground-water divide forms and causes gradients to slope either southwest or southeast. The potentiometric-surface maps of the confined aquifer show a broad area of high water levels; from this broad area, gradients slope to the southwest and east.

The ground-water level change map of the unconfined aquifer shows a mixture of increases and declines in the northern part of the study area. The changes for this area, however, are estimated due to data limitations. More data were available for the southern part of the study area, and that area shows either no ground-water level changes or declines in ground-water levels. Ground-water changes less than 10 feet can be attributed to average natural variation in ground-water levels plus average elevation inaccuracies of some wells. Mapped contours in this range are dashed to indicate these areas and to represent estimated change conditions.

The potentiometric-surface change map of the confined aquifer in the southern part of the study area shows declines in ground-water levels beyond the expected range of natural annual variation plus elevation inaccuracies.

During October 23-27, 2006, stream discharge was measured at 13 sites -7 on the Big Wood River, 3 on its tributaries, 1 on a diversion, and 2 on Silver Creek. Typically, the irrigation season and related surface-water diversion ends by mid-October, and July-October usually are the driest months of the year. However, during the week of October 23-27, 2006, a large number of tributary streams were still flowing into the Big Wood River and many active diversions were still removing water. Because of the large number of streams and diversions, not all inflows and outflows to the Big Wood River could be measured for discharge. Without measuring the discharge of each individual inflow and outflow, the comparison of flow between each measurement site is somewhat limited. However, allowing for different measurement points, the general identification of gaining and losing stream reaches on the Big Wood River and Silver Creek for this study generally agree with those identified in previous studies.

\section{Acknowledgments}

First and foremost, the authors thank the well owners who allowed access to their property and wells. Special thanks are due to A.L. Brown, B.W. Lium, and W.J. Pabich for their early support for this study, background information, and technical discussions that contributed to a better understanding of the conditions in the study area. Field measurements were performed by A.M. Campbell, D.G. Cole, R.G. Dickinson, R.W. Erickson, and R.E. Reaves, all of the U.S. Geological Survey. Both the elected and appointed officials for the cooperating governments and the cooperating nongovernmental organizations provided funding in response to their constituents' and members' concerns. Technical discussions with G.M. Clark and S.W. Lipscomb of the U.S. Geological Survey were particularly helpful in the evaluation of hydrologic trends. Technical reviews of the manuscript were provided by D.L. Berger, J.E. Hortness, K.D. Peter, and G.W. Rattray of the U.S. Geological Survey; W.J. Pabich; and T. Klahr of the Nature Conservancy.

\section{References Cited}

Aquaterra Consultants, 2006, BASINS 4.0 (beta version December 1, 2006), accessed Dec. 15, 2006, at URL: http:// www.aquaterra.com/basins4/

Berenbrock, C.E., Bassick, M.D., Rogers, T.L., and Garcia, S.P., 1995, Depth to water, 1991, in the Rathdrum Prairie, Idaho; Spokane River valley, Washington; Moscow-Lewiston-Grangeville area, Idaho; and selected intermontane valleys, east-central Idaho: U.S. Geological Survey Water-Resources Investigation Report 94-4087, scales 1:250,000, 1:317,000, 1:500,000, 3 maps on 2 sheets.

Breckenridge, R.M., and Othberg, K.L., 2006, Surficial geologic map of the Hailey Quadrangle, Blaine County, Idaho: Idaho Geological Survey Digital Web Map 55, scale 1:24,000. Available online at URL: http://www. idahogeology.org/PDF/Digital Data (D)/Digital Web Maps_(DWM)/Hailey_Surf_DWM-55-M.pdf

Brennan, T.S., Lehmann, A.K., and O'Dell, I., 2005, Water resources data, Idaho, 2005; Volume 1. Surface water records: U.S. Geological Survey Water-Data Report ID-05-1, 510 p. Available online at URL: http://pubs.usgs. gov/wdr/2005/wdr-id-05-1/

Briar, D.W., Lawlor, S.M., Stone, M.A., Parliman, D.J., Schaefer, J.L., and Kendy, Eloise, 1996, Ground-water levels in intermontane basins of the northern Rocky Mountains, Montana and Idaho: Hydrologic Atlas 738-B, scale 1:750,000, 1 sheet. 
Brockway, C.E., and Grover, K.P., 1978, Evaluation of urbanization and changes in land use on the water resources of mountain valleys: Moscow, University of Idaho Water Resources Research Institute, 104 p. plus appendix.

Brockway, C.E., and Kahlown, M.A., 1994, Hydrologic evaluation of the Big Wood River and Silver Creek watersheds Phase I: Kimberly, University of Idaho Water Resources Research Institute, Kimberly Research Center, 53 p. plus 5 appendices. Available online at URL: http:// conserveonline.org/docs/2004/06/hydrology_phase1_1994. pdf

Brown, A.L., Jr., 2000, Summary Report: Hydrologic evaluation of the Big Wood River and Silver Creek Watersheds: Ketchum, Hydronetics, 84 p.

Bureau of Reclamation, 2006, AgriMet-The Pacific Northwest Cooperative Agricultural Weather Network-AgriMet network map: accessed Nov. 14, 2006, at URL: http://www. usbr.gov/pn/agrimet/agrimetmap/agrimap.html

Campbell, P.R., 1996, Population projections for states by age, sex, race, and hispanic origin: 1995 to 2025: U.S. Bureau of the Census, Population Division, PPL-47, 105 p. Available online at URL: http://www.census.gov/population/www/ projections/ppl47.html\#tr-size-state and table 1 at URL: http://www.census.gov/population/projections/state/stpjpop. $\underline{\mathrm{txt}}$

Castelin, P.M., and Chapman, S.L., 1972, Water resources of the Big Wood River-Silver Creek area, Blaine County, Idaho: Boise, Idaho Department of Water Administration, Water Information Bulletin 28, 44 p. Available online at URL: http://www.idwr.idaho.gov/hydrologic/info/pubs/wib/ wib28-big_wood river-silver creek area.pdf

Castelin, P.M., and Winner, J.E., 1975, Effects of urbanization on the water resources of the Sun Valley-Ketchum area, Blaine County, Idaho: Boise, Idaho Department of Water Resources, Water Information Bulletin 40, 86 p. Available online at URL: http://www.idwr.idaho.gov/hydrologic/info/ pubs/wib/wib40-sun valley-ketchum area.pdf

Critchfield, H.J., 1983, General climatology, 4th ed.: New York, Prentice Hall, 453 p.

Environmental Systems Research Institute, Inc., 2007, ArcGIS 9.2 desktop help-How spline with barriers works: accessed May 10, 2007, at URL: http://webhelp.esri. com/arcgisdesktop/9.2/index.cfm?TopicName=How $\% 20$ Spline\%20with\%20Barriers\%20works

Fenneman, N.M., 1931, Physiography of Western United States: New York, McGraw-Hill, 534 p., 1 plate in pocket.
Forstall, Richard, 1995, Idaho population of counties by decennial census: 1900 to 1990: Accessed February 13, 2007 at URL: http://www.census.gov/population/cencounts/ id190090.txt

Frenzel, S.A., 1989, Water resources of the upper Big Wood River basin, Idaho: U.S. Geological Survey WaterResources Investigation Report 89-4018, 47 p. Available online at URL: http://pubs.er.usgs.gov/pubs/wri/wri894018

Godfrey, Bruce, 2000, Köppen climate classification for the conterminous United States: accessed Nov. 14, 2006, at URL: http://snow.ag.uidaho.edu/Clim_Map/koppen.htm

Helsel, D.R., and Hirsch, R.M., 1992, Statistical methods in water resources: Amsterdam, Elsevier Science Publishers, $529 \mathrm{p}$.

Insightful Corp., 2005, S-Plus 7-Statistical application software: accessed Dec. 15, 2006, at URL: http://www. insightful.com/products/splus/default.asp

Institute of Hydrology, 1980a, Low flow studies: Wallingford, Oxon, United Kingdom, Institute of Hydrology Report No. 1, 41 p.

Institute of Hydrology, 1980b, Low flow studies: Wallingford, Oxon, United Kingdom, Institute of Hydrology Report No. 3, p. 12-19.

Jones, R.P., 1952, Evaluation of streamflow records in the Big Wood River basin, Blaine County, Idaho: U.S. Geological Survey Circular 192, 59 p., 1 plate in pocket. Available online at URL: http://pubs.er.usgs.gov/usgspubs/cir/cir192

Luttrell, S.P., and Brockway, C.E., 1984, Impacts of individual on-site sewage disposal facilities on mountain valleys Phase II - Water-quality considerations: Moscow, Idaho Water \& Energy Resources Research Institute, University of Idaho, Research Technical Completion Report WRIP/371403, $74 \mathrm{p}$.

Maupin, M.A., 1992, Depth to water in the eastern Snake River Plain and surrounding tributary valleys, southwestern Idaho and eastern Oregon, calculated using water levels from 1980 to 1988: U.S. Geological Survey WaterResources Investigation Report 90-4193, scales 1:1,000,000 and 1:750,000, 2 maps on 1 sheet.

Moreland, J.A., 1977, Ground water-surface water relations in the Silver Creek area, Blaine County, Idaho: Boise, Idaho Department of Water Resources, Water Information Bulletin 44, 42 p., 5 plates in pocket. Available online at URL: http:// www.idwr.idaho.gov/hydrologic/info/pubs/wib/wib45-

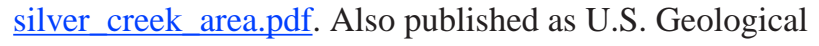
Survey Open-File report 77-456, 66 p., plates in pocket. Available online at URL: http://pubs.er.usgs.gov/pubs/ofr/ ofr77456 
Mundorff, M.J., Crosthwaite, E.G., and Kilburn, Chabot, 1964, Ground water for irrigation in the Snake River Basin in Idaho: U.S. Geological Water-Supply Paper 1654, 224 p., 6 plates in pocket. Available online at URL: http://pubs. er.usgs.gov/pubs/wsp/wsp1654

Natural Resources Conservation Service, 2006, Idaho snow survey program: accessed Nov. 14, 2006, at URL: http:// www.id.nrcs.usda.gov/snow/

Rantz, S.E., 1982, Measurement and computation of streamflow: Volume 2, Computation of discharge: U.S. Geological Water-Supply Paper 2175, 347 p.

Rantz, S.E., and others, 1982, Measurement and computation of streamflow: Volume 1, Measurement of stage and discharge: U.S. Geological Water-Supply Paper 2175, $284 \mathrm{p}$.

Schmidt, D.L., 1962, Quaternary geology of the Bellevue area in Blaine and Camas Counties, Idaho: U.S. Geological Survey Open File Report 62-120, 127 p. Available online at URL: http://pubs.er.usgs.gov/pubs/ofr/ofr62120

Smith, R.O., 1959, Ground-water resources of the middle Big Wood River-Silver Creek area, Blaine County, Idaho: U.S. Geological Survey Water-Supply Paper 1478, 61 p., 2 plates in pocket. Available online at URL: http://pubs.er.usgs.gov/ usgspubs/wsp/wsp1478

Smith, R.O., 1960, Geohydrologic evaluation of streamflow records in the Big Wood River basin, Idaho: U.S. Geological Survey Water-Supply Paper 1479, 64 p., 4 plates in pocket. Available online at URL: http://pubs.er.usgs.gov/ pubs/wsp/wsp1479

Stewart, I.T., Cayan, D.R., and Dettinger, M.D., 2005, Changes toward earlier streamflow timing across western North America: Journal of Climate, v. 18, no. 4, p. 1136-1155. Available online at URL: http://tenaya.ucsd. edu/ dettinge/stewart timing.pdf

Street, L.V., 1990, Geothermal investigations in Idaho, part 17, Geothermal resource analysis in the Big Wood River valley, Blaine County, Idaho: Boise, Idaho Department of Water Resources, Water Information Bulletin 30, part 17, 26 p., 1 plate in pocket. Available online at URL: http://www.idwr. idaho.gov/hydrologic/info/pubs/wib/wib30p17-geothermal big wood river valley.pdf

Trimble Navigation Ltd., 2007, Trimble Geomatics Office software: accessed Feb. 12, 2007, at URL: http://www. trimble.com/geomaticsoffice.shtml
U.S. Census Bureau, 2006, Census 2000 Summary File 1 (SF 1) 100-Percent Data: Accessed November 18, 2006 at URL: http://factfinder.census.gov/servlet/DCGeoSelectServlet?ds name=DEC 2000 SF1 U

U.S. Census Bureau, 2007, State \& County QuickFacts, Blaine County: Accessed February 13, 2007 at URL: http:// quickfacts.census.gov/qfd/states/16/16013.html

U.S. Department of Commerce, 2006, National Climatic Data Center: accessed Nov. 14, 2006, at URL: http://www.ncdc. noaa.gov

U.S. Environmental Protection Agency, 2006, BASINSBetter Assessment Science Integrating point and Nonpoint Sources, A powerful tool for managing watersheds: accessed Dec. 15, 2006, at URL: http://www.epa.gov/ waterscience/basins/index.html

Wahl, K.L., and Wahl, T.L., 1988, Effects of regional groundwater declines on streamflows in the Oklahoma panhandle: Symposium on water-use data for water resources management, American Water Resources Association, Tucson, Arizona, p. 239-249. Available online at URL: http://www.usbr.gov/pmts/hydraulics lab/twahl/bfi/bfi beaver river.pdf

Western Regional Climate Center, 2006, Idaho climate summaries: accessed Nov. 16, 2006, at URL: http://www. wrcc.dri.edu/summary/climsmid.html

Wetzstein, A.B., Robinson, C.W., and Brockway, C.E., 1999, Hydrologic evaluation of the Big Wood River and Silver Creek watersheds, phase II: Kimberly, University of Idaho Water Resources Research Institute, Kimberly Research Center, 136 p. Available online at URL: http:// conserveonline.org/docs/2004/06/hydrology phase2 1999. pdf

Worl, R.G., and Johnson, K.M., 1995, Geology and mineral resources of the Hailey $1^{\circ} \times 2^{\circ}$ quadrangle and the western part of the Idaho Falls $1^{\circ} \times 2^{\circ}$ quadrangle, south-central Idaho--An overview, chap. A of Worl, R.G., Link, P.K., Winkler, G.R., Johnson, K.M., eds., Geology and mineral resources of the Hailey $1^{\circ} \times 2^{\circ}$ quadrangle and the western part of the Idaho Falls $1^{\circ} \times 2^{\circ}$ quadrangle, Idaho: U.S. Geological Survey Bulletin 2064, pl. 1. 
This page intentionally left blank. 


\section{Appendix A. - Water-Level and Well Information Used to Construct Partial- Development and October 2006 Water-Table and Potentiometric-Surface Maps, Wood River Valley, South-Central Idaho.}

Appendix A data is distributed with this report as a Microsoft Excel@ spreadsheet and is available at URL: http://pubs.usgs. gov/sir/2007/5258. 
This page intentionally left blank. 
Manuscript approved for publication, October 31, 2007

Prepared by the USGS Publishing Network,

Publishing Service Center, Tacoma, Washington

Bill Gibbs

Bob Crist

Bobbie Jo Richey

Jackie Olson

Linda Rogers

Sharon Wahlstrom

For more information concerning the research in this report, contact the Director, Idaho Water Science Center

230 Collins Road

Boise, Idaho 83702-4520

http://id.water.usgs.gov 


\section{$\mathbb{E}$ 㟢}

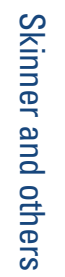

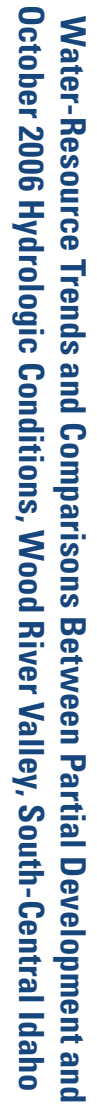

